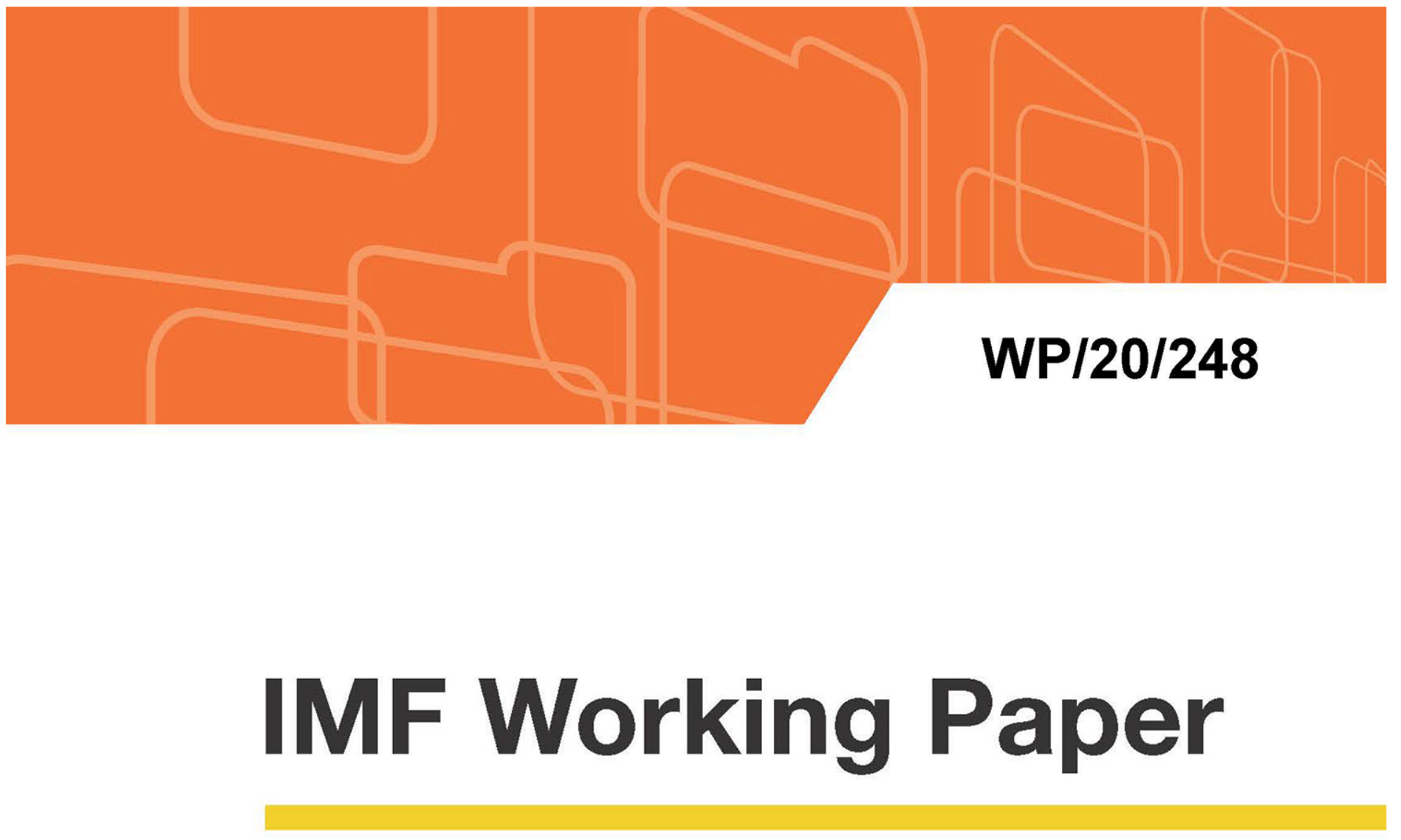

\title{
Imported Food Price Shocks and Socio-Political Instability: Do Fiscal Policy and Remittances Matter?
}

by Carine Meyimdjui

IMF Working Papers describe research in progress by the author(s) and are published to elicit comments and to encourage debate. The views expressed in IMF Working Papers are those of the author(s) and do not necessarily represent the views of the IMF, its Executive Board, or IMF management. 


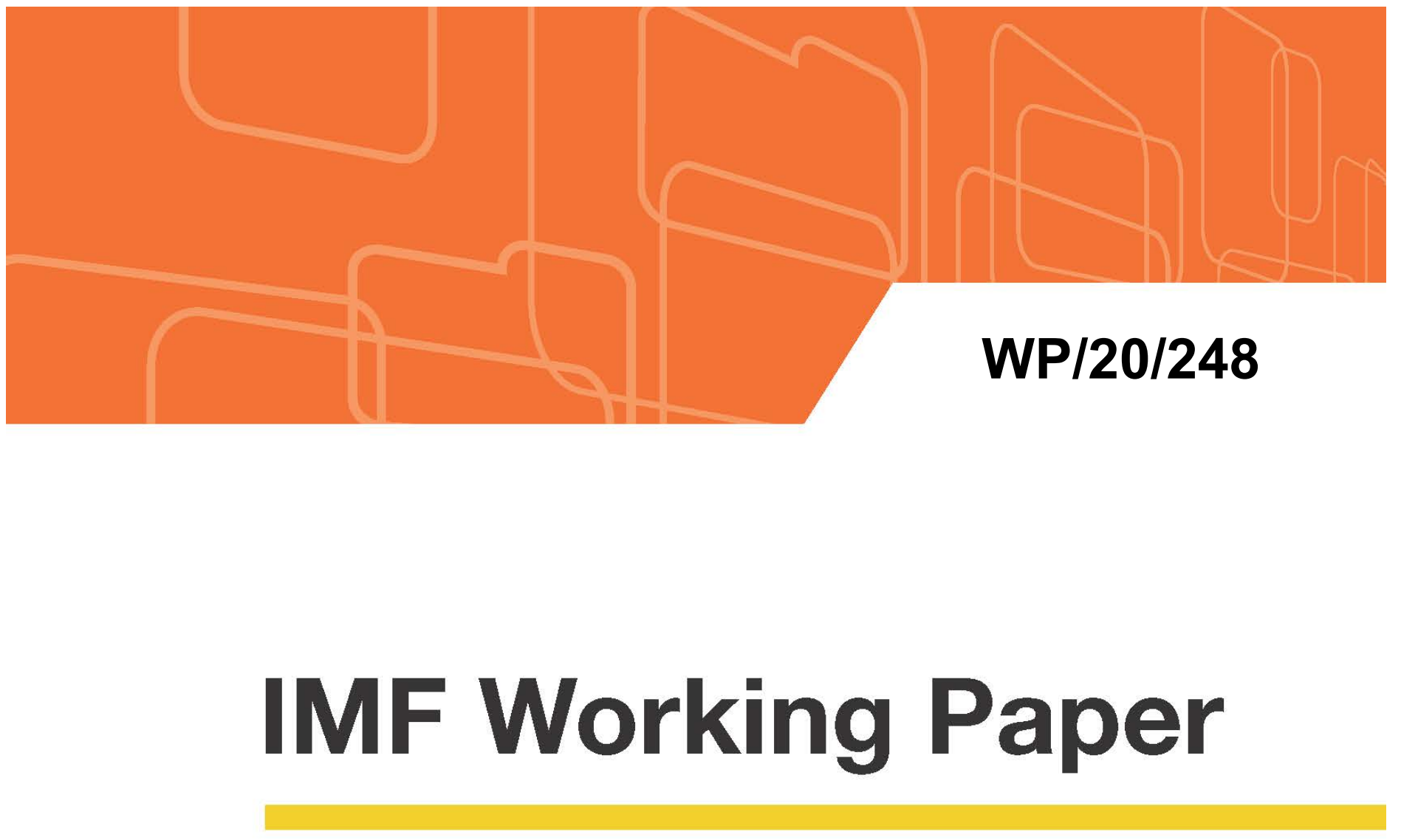

\section{Imported Food Price Shocks and Socio-Political Instability: Do Fiscal Policy and Remittances Matter?}

by Carine Meyimdjui

IMF Working Papers describe research in progress by the author(s) and are published to elicit comments and to encourage debate. The views expressed in IMF Working Papers are those of the author(s) and do not necessarily represent the views of the IMF, its Executive Board, or IMF management. 


\title{
IMF Working Paper
}

Strategy, Policy and Review Department

\section{Imported Food Price Shocks and Socio-Political Instability: Do Fiscal Policy and Remittances Matter? ${ }^{1}$}

Prepared by Carine Meyimdjui

Authorized for distribution by Johannes Wiegand

November 2020

\section{IMF Working Papers describe research in progress by the author(s) and are published to elicit comments and to encourage debate. The views expressed in IMF Working Papers are those of the author(s) and do not necessarily represent the views of the IMF, its Executive Board, or IMF management.}

\begin{abstract}
Using a panel of 101 low- and middle-income countries with data covering the period 1980-2012, this paper applies various econometric approaches that deal with endogeneity issues to assess the impact of food price shocks on socio-political instability once fiscal policy and remittances have been accounted for. It focuses on import prices to reflect the vulnerability of importer countries / net-buyer households to food price shocks. The paper finds that import food price shocks strongly increase the likelihood of socio-political instability. This effect is greater in countries with lower levels of private credit and income per capita. On the other hand, while remittances seem to dampen the adverse effect of import food price shocks on socio-political instability in almost all countries, the mitigating role of fiscal policy is significant only in countries with low-levels of private credit.
\end{abstract}

JEL Classification Numbers: H56; Q02; Q54

Keywords: import food price shocks; political instability; remittances; fiscal policy. Author's E-Mail Address: CMeyimdjui@,imf.org

\footnotetext{
${ }^{1}$ This paper is part of a Macroeconomic Research Project in Low-Income Countries supported by the UK Foreign, Commonwealth \& Development Office (FCDO). The author is extremely thankful to Roland Kpodar, Ayerst, Stephen Ippei Shibata and Tewodaj Mogues for their incisive and invaluable comments on this paper.
} 
III. DATA AND STYLIZED FACTS

IV. EMPIRICAL SETTINGS

V. CONCLUSION

References

\section{FIGURES}

1. Food Price Shocks and Food Price Growth

2. Socio-political Instability: Some Heterogeneities

3. Patterns of Food Commodity Prices from 1980 to 2012

4. Socio-political instability with Fiscal stimuli versus no Fiscal Stimuli

5. Remittances and Food Price Shocks

\section{TABLES}

1. Correlation Matrix

2. Baseline Results: Food Price Shocks and Conflicts: The Roles of Fiscal Policy and Remittances

3. Food price shocks and socio-political instability: geographical heterogeneities

4. Food Price Shocks and Political Instability: The Role of Fiscal Policy

by Level of Income

5. Food Price Shocks and Political Instability: by Level of Private Credit Access

6. Positive Food Price Shocks and Civil Conflicts: The Roles of Fiscal

Policies and Remittances

$\underline{22}$

7. Food Price Shocks and Expropriations: The Roles of Remittances and Fiscal Policy ….... $\frac{31}{32}$

8. Food Price shocks and instability: Additional Robustness Checks ............................... $\frac{32}{33}$

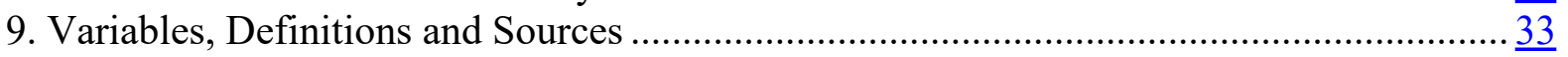

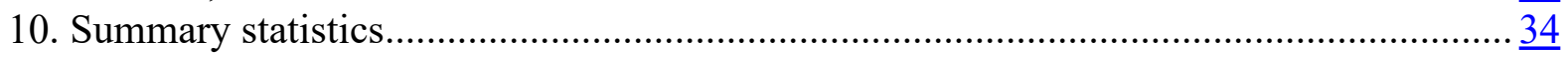

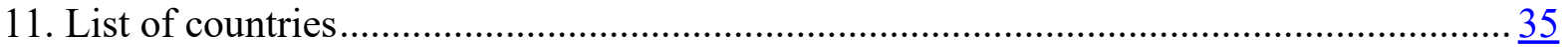




\section{INTRODUCTION}

Political stability is a prime objective any government must achieve to promote sustainable growth and social well-being. As pointed out by Gupta (2007), governments in unstable political regimes fall short in constructing and properly defining property rights. The surge in food prices over the past decade, coupled with poor climatic conditions, has stirred social unrest and instability in many countries. The effects have been found to be more acute in countries where households have been severely affected by unexpected events. Indeed, increasing hunger has compelled citizens to take to the streets, demanding and demonstrating for their rights. For instance, the surge in food prices is a factor of unrest (Barnett, 2003, Bellemare, 2015). In the same vein, it has been documented that the surge in food prices fueled unrest during the Arab spring (Arezki and Bruckner, 2011; Brückner and Ciccone, 2010; Ortiz and Cummins, 2012; Raleigh, Choi, and Kniveton, 2015). The literature on such issues has established that fighting vulnerability to food price shocks is a key element in achieving political and social stability.

Generally, in such situations, governments resort to certain policy tools to improve food access and instill socio-economic stability. With this in mind, Smith (1997) points out that the legitimacy of the government depends on its capacity to provide its citizens with food security. In the short term, the measures adopted may include food aid, subsidies, price administration, and any other mechanisms designed to support household purchasing power or food access. In the medium to long term, the most comprehensive responses consist of significantly reinforcing the agricultural system while taking weather conditions into account (Change, 2014; Smit and Skinner, 2002).

It has been demonstrated that remittances received play a mitigating role with regard to economic instability (Craigwell, Jackman, and Moore, 2010, Combes and Ebeke, 2011, Chami, Hakura, and Montiel ,2012; Ebeke and Combes, 2013, Combes et al., 2014).Migrants may be prone to sending money home in times of crisis to help their relatives meet their needs, thereby reducing the probability of lose access to food.

These actions can, in particular, apply to lower-income countries that are generally more exposed to adverse shocks without sufficient safety nets and insurance tools for the purposes of mitigation and resilience.

Hence, while government reactions and remittances may play a crucial role with regard to sociopolitical instability in times of adverse food price shocks, this point has (to the author's knowledge) received very limited attention in the literature. In trying to bridge this gap, this paper aims to assess whether fiscal policy and remittances make any difference to the impact of import food price shocks on socio-political instability.

To the author's knowledge, only one paper by Aguirre (2016) assesses the quantitative impact of fiscal policy on the likelihood of conflict occurring in times of economic shocks. His study relies on agricultural and mineral export price shocks in African countries and finds that conflict occurrences are dampened by the government's countercyclical fiscal measures.

To add to this literature, the paper hypothesizes that import food price shocks could also affect political instability in developing countries. As many of them are net food importers (with many net food-buyer households), import food price shocks, and more precisely positive ones, could be 
a trigger of serious hunger episodes leading to political or social unrest. Another novelty of this paper is that instead of considering only government consumption expenditure growth as Aguirre (2016) does, it also considers the cyclically-adjusted government consumption expenditure that could be more suitable with a view to underlining discretionary policy implemented in times of unpredictable shocks.

The research uses a large panel of data including 101 low- and middle-income countries over the period of 1980-2012. ${ }^{2}$ As the dependent variables are qualitative, with a large number of observations focused on one modality (0), the Ordinary Least Square would lead to biased estimates. Consequently, the paper calls on the Probit and the maximum likelihood Tobit estimator (Finlay and Magnusson, 2009 and Miranda and Rabe-Hesketh, 2006). The results show that positive food price shocks significantly increase the probability of civil conflict, government crises, and expropriations. Conflict intensity is also likely to be more prevalent in times of food price shocks. Fortunately, remittances dampen this adverse effect of food price shocks on the likelihood of civil conflicts and expropriations. It is found that the dampening impact of fiscal policy is barely significant, except in countries with low levels of private credit and income. Results remain similar when other controls are added and when the regional dummies are factored in.

The rest of the paper is structured as follows: the second section briefly reviews the literature. In the third section, data and stylized facts are presented. The fourth section examines the empirical settings and findings, while the fifth section concludes.

\section{LITERATURE REVIEW}

Arezki and Bruckner (2011) find that food price shocks in low-income countries lead to a decrease in democratic institutions and an increase in anti-government demonstrations, riots and conflicts. With regard to the main transmission mechanisms, their results show that food price shocks lead to a significant decrease in private consumption and an increase in both income inequalities and consumption inequalities. This result is similar to that of Hendrix and Brinkman, 2013, Smith, 2014, and Raleigh, Choi, and Kniveton, 2015). In the same vein, using monthly data on food prices and social unrest for the period January 1990 - January 2011, Bellemare (2015) finds that the increase in food prices led to an increase in political unrest.

The literature on the impact of commodity prices on political stability has, for the most part, focused on the extent to which the increase in export commodity prices allows politicians to finance protestations and demonstrations (rebellion) or, when certain social groups feel aggrieved with regard to gains sharing (Draman, Malone, and Berdal, 2000; Collier and Hoeffler, 2004; Sobek and Boehmer ,2009; Pinstrup-Andersen and Shimokawa, 2008). In parallel to this extensive literature, Besley and Persson (2008) point out that any rise in import food prices that contributes to a fall in purchasing power could also contribute to increasing the probability of conflict.

\footnotetext{
${ }^{2}$ The paper could not obtain detailed data on specific food price shocks and imported quantities.
} 
With regard to the relationship between fiscal policy and socio-political instability, it has been found that high government expenditure tends to be associated with less political upheaval, as governments call on preventive measures involving spending (Barro and Sala-i-Martin, 1995; Devereux and Wen, 1998; Annett, 2000; Aisen and Veiga, 2013). More recently, Agnello et al. (2017) show that successful fiscal stimuli dampen the negative impact of income inequality on the likelihood of government crisis. ${ }^{3}$

Only a limited number of studies, however, have assessed the quantitative impact of the government's stabilizing role in times of shocks. This could be due to a matter of data unavailability. Aguirre (2016) investigates the impact of fiscal policy on the likelihood of conflict in times of economic shocks. He uses a sample of 44 countries over a period running from 1960 to 2013. Aguirre's shock variables are based on agricultural and mineral commodity prices. His results demonstrate that the probability of conflict decreases with countercyclical fiscal policy. More explicitly, his study did not find any significant relation between government consumption expenditure growth (used as a fiscal policy variable) and the likelihood of conflict without an interaction with commodity price shocks. This is the only paper, according to available information, that has tried to assess the role of government stabilization policies on the likelihood of conflict.

It is acknowledged that remittances generally play a countercyclical role in the beneficiary economy (Craigwell, Jackman, and Moore, 2010; Chami, Hakura, and Montiel, 2012). More interestingly, remittances have been found to dampen the effect of adverse shocks on household consumption (Combes and Ebeke, 2011; Ebeke and Combes, 2013; Combes et al., 2014).

A small number of papers have studied the relationship between socio-political instability and remittances. Using a sample of both developing and developed countries, Ziesemer (2011) finds evidence that political instability is among the factors driving net remittances in developing countries. Baser and Swain (2008) drafted a policy note supporting the role of remittances in reducing adverse effects in times of crisis. All these papers are nevertheless mostly theoretical and do not involve any data analyses.

This paper attempts to bridge this gap by empirically assessing the effect of remittances on sociopolitical instability in times of import food price shocks. Its main hypotheses are presented as follows: (i) import food price shocks increase the likelihood of socio-political instability; (ii) this effect is dampened by remittances and countercyclical fiscal policy. The paper uses two fiscal policy variables based on government consumption expenditure, which is likely the most used (part of government expenditure) in times of unpredictable shocks. Like Aguirre (2016), the yearly growth of government consumption expenditure is considered. Another fiscal policy variable used here is calculated following the construction of the fiscal stimuli variable implemented by Agnello et al.( 2017). ${ }^{4}$

\footnotetext{
${ }^{3}$ They define fiscal stimuli as the increase in the cyclically-adjusted balance that is followed by economic growth prospects in the two subsequent years (calculated using the methodology by Blanchard (1990)).

${ }^{4}$ As a matter of fact, the paper does not use their fiscal policy variable, as they rely both on revenue and expenditure.
} 


\section{DATA AND STYLIZED FACTS}

This study focuses on 101 middle- and low-income countries. Data challenges force the research to limit the analyses to the period 1980-2012. For the same reason, as displayed in table 10 (appendix), the number of countries and observations is not the same for all the socio-political instability variables considered. Food price shocks are derived from price data constructed using IMF WEO data on prices and FAO Trade and Statistics data on quantities. Given that developing countries are in general price takers, this research uses international market price data. The paper recognizes that the transmission of international prices to the domestic market might differ from one country to another. Unfortunately, the paper could not obtain detailed data on specific food price shocks and imported quantities. Considering imported quantities also enables the research to keep food price shocks exogenous.

Considering these international prices allows the research to limit the endogeneity issue that may arise from the fact that prices in each country may depend on quantities demanded and other factors prevailing in the country. Since the objective of the research is to underline the household/country vulnerability issues with regard to imports, the paper only uses import food prices, as these appear as a cost for an importing country/household. The socio-political instability variables are drawn from the Upsala/PRIO and Cross-National Time-Series Data Archive (CNTS). Regarding the fiscal policy indicator, because consistent data on the main tools (food subsidies, wage adjustment, food aid, etc.) that governments generally use for the purposes of stabilization are not available for the sample, the fiscal policy variables are calculated on the basis of government consumption expenditure. ${ }^{5}$ Details about all variable calculations are provided below. Furthermore, the general definitions and sources of all variables used in this study are given in table 8 (Appendix).

Interest variables. These include the food price shock variables and fiscal policy variables.

- Food price shocks. Food price shocks are calculated using an econometric approach developed by Deaton and Miller (1995) and used by Collier and Dehn (2001) and Combes et al. (2014). To obtain the price shock variable, the paper determines the food price index for each country using the relative values of the most common imported food commodities during the period. This price index is the commodity price average, weighted by the average quantities of each commodity during the study period. ${ }^{6}$ Such commodities include wheat, sugar, soybeans, soybean oil, maize and rice, and their world prices are presented in figure 3 (appendix). ${ }^{7}$ The calculation is done as follows:

First, using the yearly prices and imported quantities, the paper computes $w_{i, j} \cdot$ which is the average value of commodity j imported by country i over the relative period (1980 to 2012), and is specified as follows:

\footnotetext{
${ }^{5}$ The paper does not exclude the possibility that even capital expenditure could be used at the end of shock mitigation or adaptation processes, but the intuition is that, as price surges give rise to an immediate loss of purchasing power and that poor households do not have sufficient savings or insurance of any kind for rainy days, hunger and food insecurity quickly increase and need to be handled in the short term.

${ }^{6}$ Since quantities generally respond to price variations, considering the entire period-average quantity allows the research to limit these price effects on quantities.

${ }^{7}$ See FAO, IMF, and UNCTAD (2011) report
} 


$$
w_{i, j} \cdot=\frac{P_{j \bullet} Q_{i, j}}{\sum_{j=1}^{6} P_{j} \cdot Q_{i, j}}
$$

where $Q_{i, j}$ is the total (period average) quantity of commodity j imported by country $i$. Secondly, for each country and each year, the price index is given by

$$
P_{i, t}=\prod_{j=1}^{6} P_{j, t}^{w_{i, j}}
$$

where $P_{i, t}$ is the price index in country $\mathrm{i}$ for year $\mathrm{t}$, and $P_{j, t}$ is the price of commodity $\mathrm{j}$ in the world market for time $t$ (same price for all countries). The paper considers 1990 as the price base year to make yearly price comparisons, as this also allows to consider more countries because the former Soviet countries' data were recorded more regularly from that year. ${ }^{8}$

Third, for each country, the paper regresses the price index on an intercept, the trend, and the first and second order lags of the normalized food price index. ${ }^{9}$ This allows to control for any predictability in food prices, thereby eliminating the autocorrelation). By doing so, the paper attempts to obtain food price residuals which are as unpredictable as possible. The regression is specified as follows:

$$
\operatorname{Ln}\left(P_{i, t}\right)=\alpha_{i, 0}+\alpha_{i, 1} \text { time }+\theta_{i, 1} \operatorname{Ln}\left(P_{i, t-1}\right)+\theta_{i, 2} \operatorname{Ln}\left(P_{i, t-2}\right)+\varepsilon_{i, t}
$$

From the latter equation, the research extracts the residual term and deduce the shock variables as follows:

(i) The first price shock variable is calculated by regressing, for each individual country, the price index variable on its two first lags, the trend and an error term. ${ }^{10}$ The residual of this regression is taken as the shock variable. (ii) The second price shock variable is the number of positive values of the residual of equation (3) within a period of four non-overlapping years. This is a proxy of the frequency of positive food price shocks. ${ }^{11}$

- Fiscal policy. The paper uses two fiscal policy variables: (i) The first, is the annual growth rate of government consumption expenditure as a share of GDP; (ii) the second is a discretionary fiscal variable, and is a fiscal stimuli proxy calculated in two steps.

In the first step, the paper extracts the residual of the country-by-country regression of government consumption expenditure on the cyclical component of the output gap, inflation and inflation squared:

\footnotetext{
${ }^{8}$ The year 1990 is taken as the base year because the Cold War (1985-1990) ended at that year, making significant changes on countries' policies, with a potentially significant effect in the economic realm.

${ }^{9}$ It should be noted that the estimate results of equation (3) did not change considerably when the paper introduced only 1 lag or 3 lags of the dependent variable.

${ }^{10}$ In fact, the world market price may not necessarily have the same pass-through across countries. Depending on each country's characteristics, including the information structure in place, the given price in the world market may differ from the same price at the domestic level.

11 The paper directly follows the methodology use by Combes et al. (2014) to compute their food price shock variables.
} 


$$
\text { GOV }_{t}=\alpha_{8}+\alpha_{9} \text { Cycle_GDPgrowt }_{t}+\alpha_{10} \text { Inflation }_{t}+\alpha_{11} \text { InflationS }_{t}+\varepsilon_{t}(5)
$$

where: $G O V_{t}$ is the current value of government consumption expenditure as a share of GDP, Cycle_GDPgrowth is $_{\text {in }}$ the cyclical component of the annual GDP per capita growth. The paper uses this variable as a proxy of the output gap that is considerably less well documented for developing countries included in the sample. This cyclical component is obtained using the Hodrick-Prescott filter (following Ravn and Uhlig (2002), the smoothing parameter $\lambda=6.25$ ), Inflation $_{t}$ and InflationSQ $Q_{t}$ are the annual change (as a \%) of the consumer price index and its square respectively. Additionally, since Cycle_GDPgrowth is a generated variable, its coefficient is corrected in each country's regression using a bootstrap process with 250 replications.

The residual of this regression is considered as a proxy of the discretionary component of government consumption expenditure. This methodology directly follows (Fatas and Mihov, 2003; Agnello and Sousa, 2009) who compute discretionary fiscal policies based on government consumption and fiscal balance.

In the second step, the research computes the standard deviation of the residual extracted over 4 successive years, then it constructs the dummy variable that takes a value, a dummy variable that takes a value of 1 if the residual is higher than the sub-period standard deviation and 0 otherwise is also constructed. Using that measure, the research attempts to consider the episodes of large discretionary government consumption expenditure. In the rest of the paper, this variable is called fiscal stimuli.

Dependent variables. The paper uses various measures of socio-political instability.

- Civil conflict. This is a dummy variable that takes a value of 1 if a country experiences an intrastate conflict with more than 25 battle deaths and 0 otherwise.

- Conflict intensity. This variable is the number of conflicts with more than 25 battle-related deaths throughout the year.

- Expropriations. This is a dummy variable that takes a value of 1 if there is any systemic elimination of political opposition during the year by means of jailing or execution, and 0 otherwise.

- Government crisis. This is a dummy variable that takes a value of 1 if there is any rapidly evolving context "that threatens to bring the downfall of the present regime-excluding situations of revolt aimed at such overthrow" and 0 otherwise. For each country, both expropriations and government crises are measured at the domestic level and are drawn from the Cross-National Time-Series Data Archive (CNTS).

Control variables. The paper also controls for some relevant macroeconomic variables. 
- GDP per capita growth. This is used to reflect general economic health. To address the endogeneity that could arise when introducing this variable into the regression, its first lag as an instrument. This variable is expected to have a negative effect on the probability of socio-political instability.

- IMF-World bank poverty reduction program: this dummy variable is borrowed from the database computed by Dreher, Sturm, and Vreeland (2009). The paper uses it to control for the fact that, as many developing countries have been implementing structural reforms over the past two decades, these reforms may have improved the socio-political environment. ${ }^{12}$

- Financial crisis: this variable counts the number of macroeconomic crises for each year in each country. The paper considers Systemic Banking Crisis, Currency Crisis. Sovereign Debt Crisis and Sovereign Debt Restructuring, all of which are dummy variables that take a value of 1 in a year when a country experiences a crisis and 0 otherwise. These variables were extracted from information provided by the Laeven \& Valencia (2018) database. The macro financial variable is used to control for macro financial situations that would lead to distress and offset socio-political stability, Gries \& Meierrieks, (2013).

All variables and their definitions are presented in table 9, with their general summary statistics presented in table 10 (appendix). The list of countries can be found in table 11 (appendix).

Stylized facts. This section presents some stylized facts regarding import food price shocks, socio-political instability, fiscal policy and remittances in the sample.

In figure 1, the paper presents the evolution of the shock variable (computed above) and food price growth from 1980 to 2012. The price-related lines represent the median value of each variable in the given year. The chart clearly shows that for the entire period, food price growth is almost stable, while the shock variable is highly unstable, particularly between 2006 and 2007, and between 2010 and 2011.

\footnotetext{
${ }^{12}$ According to the IMF (2015), structural reforms have a positive impact on economic performance. In the same vein, the paper hypothesizes that structural reforms are also conducive to the reduction of socio-political instability.

According to Agnello et al. (2017), income inequality is a strong determinant of socio-political instability, however, the paper does not include this variable in the final results as the number of observations is very low and do not lead to robust results.
} 
Figure 1. Food Price Shocks and Food Price Growth

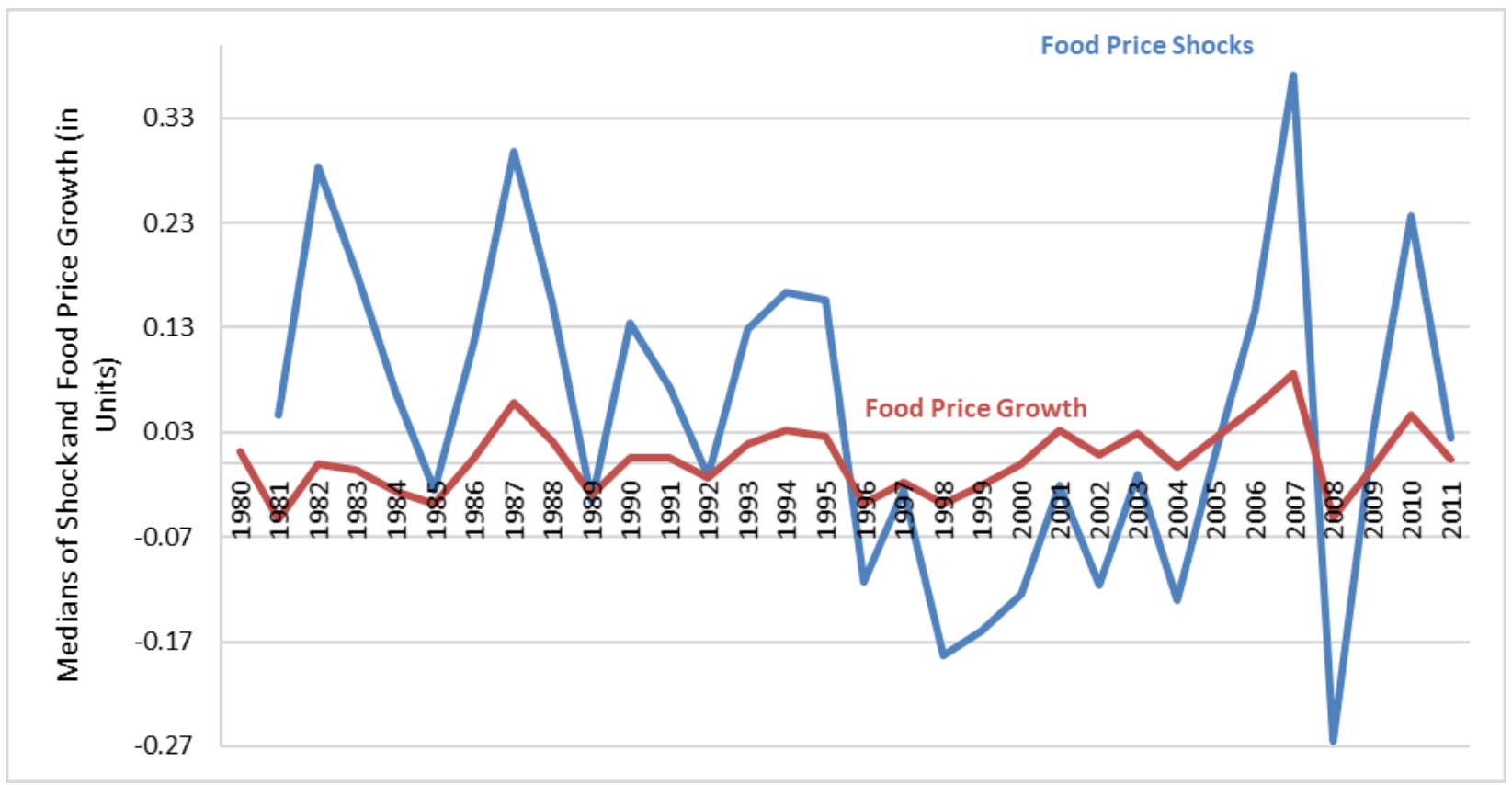

Source: Authors, using data from FAO Statistics, IMF WEO and the World Bank Data. Price growth is the growth value of the food price index computed in equation (2), while shock is the residual of equation (3).

The following table presents the correlation coefficients between socio-political variables and price shock variables. The statistics clearly show that food price shocks and positive food price shocks are positively and significantly associated with socio-political instability variables.

Table 1. Correlation Matrix

\begin{tabular}{|l|l|l|l|l|l|l|l|l|l|}
\hline & Shock & $\begin{array}{l}\text { Positive } \\
\text { Shock }\end{array}$ & Conflict & $\begin{array}{l}\text { Conflict } \\
\text { Intensity }\end{array}$ & $\begin{array}{l}\text { Governme } \\
\text { nt Crisis }\end{array}$ & $\begin{array}{l}\text { Expropri } \\
\text { ations }\end{array}$ & $\begin{array}{l}\text { Government } \\
\text { Expenditure }\end{array}$ & $\begin{array}{l}\text { Fiscal } \\
\text { Stimuli }\end{array}$ & Remittances \\
\hline & $\mathrm{f}$ & & & & & & & & \\
\hline Shock & 1.00 & & & & & & & & \\
\hline Positive Shock & $0.45^{*}$ & 1.00 & & & & & & & \\
\hline Conflict & $0.11^{*}$ & $0.16^{*}$ & 1.00 & & & & & & \\
\hline Conflict Intensity & $-0.12^{*}$ & $-0.14^{*}$ & $-0.82^{*}$ & 1.00 & & & & & \\
\hline Government Crisis & 0.03 & $0.09^{*}$ & $-0.13^{*}$ & 0.03 & 1.00 & & & & \\
\hline Expropriations & $0.17^{*}$ & $0.16^{*}$ & 0.06 & -0.00 & 0.06 & 1.00 & & & \\
\hline $\begin{array}{l}\text { Government } \\
\text { Expenditure }\end{array}$ & -0.09 & $-0.12^{*}$ & -0.03 & 0.03 & 0.04 & 0.02 & 1.00 & & \\
\hline Fiscal Stimuli & 0.06 & 0.03 & 0.07 & -0.08 & 0.04 & 0.04 & $-0.17^{*}$ & 1.00 & \\
\hline Remittances & -0.05 & -0.04 & $-0.14^{*}$ & $0.16^{*}$ & 0.04 & -0.06 & 0.08 & 0.01 & 1.00 \\
\hline
\end{tabular}

Source: Authors computations, using FAO Statistics IMF WEO, Prio/Upsala and CNTS datasets. *(5\% significant). In this table, government expenditure refers to government consumption growth.

In light of the above, it could be relevant to assess whether there might be a means of dampening such adverse effects of import price shocks. This paper focuses on net received remittances and fiscal policy (based on government consumption expenditure). 
To see whether there could be any difference in socio-political instability depending on the level of remittances, the sample is split into two, called lower and higher remittances (which respectively refer to countries whose net remittances received lay below the sample median value of remittances and those whose net remittances received lay above the median). This median value is equal to $2.5 \%$ of GDP. The average probability of civil conflicts and government crisis variables are plotted for each sub-sample according to the level of remittances. As shown in figure 2, both civil conflicts and government crises seem to be more likely in countries with lower level of remittances. Thus, it is possible that the more people receive remittances, the less they would want to join unrest and other demonstrations. Additionally, figure 5 (appendix) shows that remittances tend to be more important when food price shocks are larger.

The papers also aims to see whether there could be any difference in socio-political instability depending on fiscal policy. To do that, as with remittances, the paper splits the sample into two sub-samples depending on the level of fiscal stimuli (by unpredictably increasing their government consumption expenditures). After that, the paper plots the average values of conflict intensity, the probability of civil conflict and the probability of government crises in figure 4 (appendix), there is no evidence that countries that unpredictably increase their government consumption expenditures experience lower socio-political instability than those that do not. This could be an indication that the amount of fiscal policy has generally not been enough to dampen socio-political instability.

Figure 2. Socio-political Instability: Some Heterogeneities

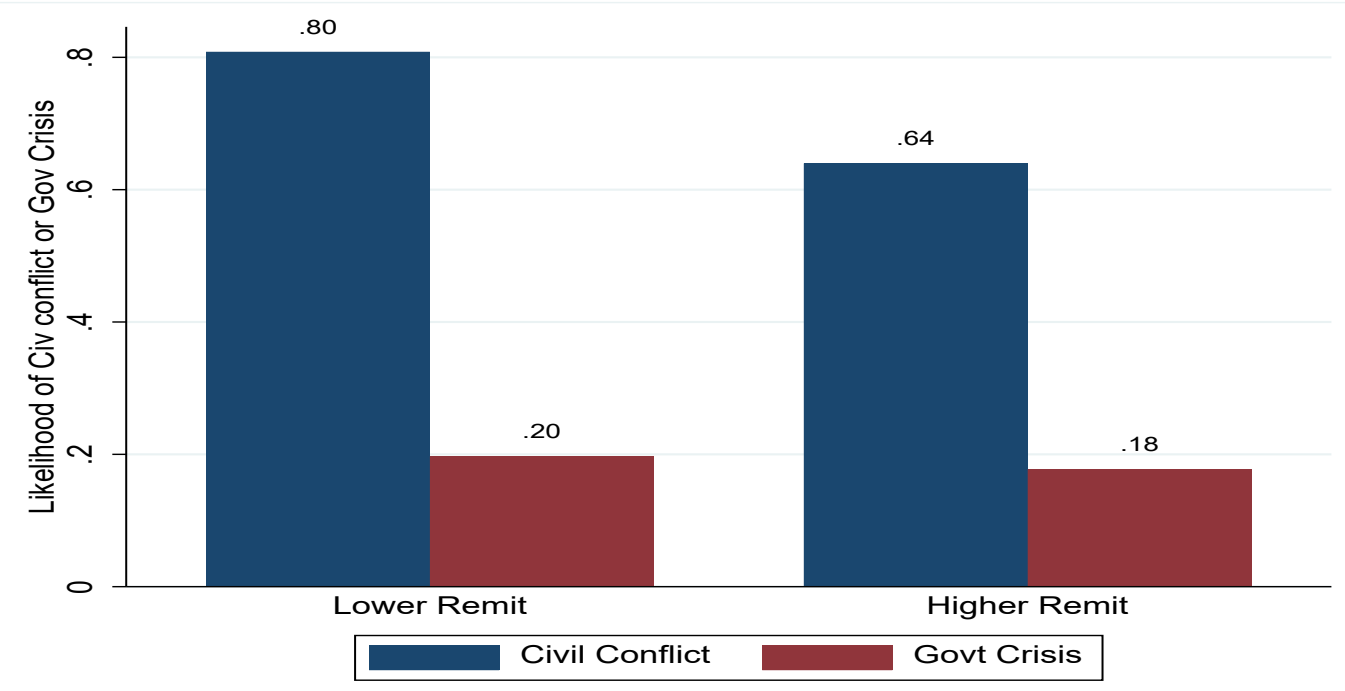

Source: Authors, using data from Prio/Upsala and World Bank Indicators.

However, all these results are far from providing any meaningful conclusions, as these stylized facts are based on simple correlations and have not considered multiple factors that may also affect socio-political instability. The research therefore pursues the analysis in the following section with an econometric assessment. 


\section{EMPIRICAL SETTINGS}

The empirical investigation of the relationship between political instability and food price shocks in the presence of fiscal policy and remittances is based on the following equation:

$$
\begin{aligned}
& \text { Instability }_{i, t}=\alpha_{1}+\alpha_{2} \text { Shock }_{i, t}+\alpha_{3} \text { Fiscalpol }_{i, t}+\alpha_{4} \text { Re mit }_{i, t}+\alpha_{5} \text { Shock }_{i, t} * \\
& \text { Fiscalpol }_{i, t}+\alpha_{6} \text { Shock }_{i, t} * \text { Remit }_{i, t}+\alpha_{7} \text { GDP }_{i, t}+X_{i, t}+w_{t}+\varepsilon_{i, t}
\end{aligned}
$$

where Instability is the socio-political instability variable (Conflict, Expropriations, Gov crisis and Conflict Intensity); Shock is the food price shocks variable; Remit is the personal received remittances as a (share of GDP); Fiscalpol is the fiscal policy variable considered, namely Gov Expenditure and Fiscal stimuli); $\varepsilon_{i, t}$ is the residual, while $w_{t}$ is the year fixed effect which allows to control for all factors that are common to all countries at the same time. $X$ is the vector of other control variables. $\alpha_{2}$ is expected to be positive, meaning that the paper expects socio-political instability to increase with food price shocks. It is also expected that fiscal policy and remittances dampen the positive effect of food price shocks on socio-political instability: in other words, $\alpha_{5}$ and $\alpha_{6}$ are expected to be negative.

The dependent variables are categorical, thus the traditional OLS estimator might be biased because due to random errors (Maddala and Lahiri 1992). Hence, the paper resorts to probability estimators that are more suitable for this structure of a limited-dependent variable. The paper resorts to the Probit estimator for the dependent variables that are coded 0 and $1 .{ }^{13}$ For the dependent variable that is number of conflicts in each country during a given year, the research resorts to the Tobit estimator. Furthermore, since the dependent variables present a high concentration of observations around one modality (0), the Probit (or Logit) estimators could lead to upward-biased estimates of the intercept, while other coefficients will tend to be downwardbiased. Thus, to check the robustness of the estimates, the paper runs some estimations on all the dependent variables using the simple Tobit estimator with its maximum likelihood option Miranda and Rabe-Hesketh (2006). The research addresses the endogeneity issues by using the IV Probit and IV Tobit models as suggested by Finlay and Magnusson (2009). This is the same methodology used by Agnello et al. (2017), who used the same dependent variable as this paper. In the robustness checks, the paper also presents a number of regressions using the two-stage least square IV estimator.

Additionally, since certain explanatory variables are obtained from estimations (food price shocks and fiscal policy), their standard errors (but not their coefficients) could be biased (Woolridge 2002). To check whether this applies to the results, the paper bootstraps the standard errors of the Probit estimates by 250 replications.

In all the regressions, the paper controls for time fixed effects. The interpretation of the coefficients given by the results is not straightforward for the categorical explanatory variables, such as fiscal stimuli, as these coefficients are not as directly reliable as marginal effects (Greene

\footnotetext{
${ }^{13}$ The estimates using Probit and Logit models are very close. In this paper, the paper only presents results obtained from the Probit regressions.
} 
2012). However, the signs of these coefficients are the same for the corresponding marginal effects.

\section{a) Baseline Results.}

Table 2 reports the results of the effect of food price shocks on the probability of civil conflict and conflict intensity. In column 1, the paper regresses food price shocks alone to the likelihood of civil conflict. The results clearly show that food price shocks positively and significantly affect the dependent variable. However, as there should certainly be other factors that condition the likelihood of civil conflicts, the paper adds additional variables in the next columns. In column 2 , controls include net personal remittances received, government consumption expenditure growth (Gov Expenditure), and the interaction terms between food price shocks and remittances and between food price shocks and Gov Expenditure. As the table shows, while food price shocks do not seem to affect the probability of civil conflicts significantly, remittances significantly reduce the probability of civil conflict and when interacting remittances and food price shocks, the coefficient is also negative and statistically significant, meaning that remittances dampen the positive effect of food price shocks on the occurrence of civil conflict. However, neither consumption expenditure growth nor its interaction term with food price shocks is significant, which would seem to suggest that fiscal policy consisting of increasing government consumption expenditure does not significantly affect the occurrence of civil conflicts. ${ }^{14}$ Nevertheless, in column 4, when the paper uses the fiscal stimuli variable and its interaction term with food price shocks in place of government expenditure growth and its interaction term with food price shocks, the results show that the fiscal stimuli variable does not seem to affect the likelihood of civil conflict significantly, although its interaction term with food price shocks significantly and negatively affects the likelihood of civil conflict.

In columns 3 and 5, GDP per capita growth, the dummy of the IMF-World Bank poverty reduction program, and the financial crisis variable are added. ${ }^{15}$ As these additional controls might come with potential endogeneity, not only because GDP growth may be correlated with the fact of receiving a poverty reduction program and experiencing a financial crisis, but also because all these additional controls would be correlated with both remittances and any fiscal responses, the paper resorts to the IV Probit and IV Tobit to address this endogeneity whereby it considers the first lags of personal received remittances of GDP per capita growth as the instruments for remittances and GDP per capita growth ${ }^{16}$. While none of these additional controls appear to significantly affect the likelihood of civil conflict, contrary to columns 2 and 4 , it is shown that the food price shocks variable individually becomes statistically significant. Furthermore, the results regarding remittances and fiscal policy do not change. ${ }^{17}$ This result thus adds to the

\footnotetext{
${ }^{14}$ The lack of significance of fiscal policy could be attributable to its definition and computation in the context of this paper. However, the paper does do not have another more reliable methodology to rely on in computing it. This lack of significance could also be understandable in contexts where the share of fiscal response to unrest is very small.

${ }^{15}$ The results remained unchanged when controlling for the change in political regimes and nominal exchange rate (results available upon request).

${ }^{16}$ The paper first attempted to use the occurrence of natural disasters as the instrument of GDP per capita growth, but as there are too many missing data on that variable, it was not possible to obtain robust results. Another potential instrument of GDP per capita growth could have been the instability of terms-of-trade, but the research does not use it here, as it could be correlated with the food price shocks variable.

${ }^{17}$ The paper also added an income inequality variable (from Standardized World Income Inequality Database data), but because of missing data,
}

(continued...) 
literature supporting the idea that remittances are countercyclical and smooth the adverse impacts of external shocks on income and consumption instability, (Craigwell, Jackman, and Moore, 2010; Combes and Ebeke, 2011). Indeed, in addition to the existing literature, these results support the idea that the dampening role of remittances is also valid for socio-political instability.

In column 6 , the paper runs the same regression as in column 3 by considering conflict intensity (measured as the number of conflicts with more than 25 deaths) as the dependent variable. For this regression, the paper resorts to the IV Tobit estimator. According to the results, food price shocks positively and significantly affect conflict intensity, but there is no evidence that remittances and fiscal policy dampen the effect of food price shocks on conflict intensity.

These results generally remain consistent when the standard errors of food price shocks, fiscal stimuli and the interaction term between food price shocks and fiscal stimuli (results are available upon request) are bootstrapped. The unbiased standard errors were generally slightly higher than the standard errors obtained from the estimates without bootstrapping, meaning that the significance of the interest variables were underestimated.

Quantitatively speaking, according to column 3, everything else being equal, a deviation of the food price of one unit from its long run trend leads to an increase of 0.8 to $4 \%$ in the likelihood of civil conflict. On the other hand, an additional $1 \%$ of received remittances (in share GDP) leads to a decrease in likelihood of civil conflict of $0.09 .{ }^{18}$

Regarding the results according to which remittances significantly reduce the probability of civil conflicts but do not affect the intensity of conflict, even though the paper was expecting a negative and significant effect of remittances on both of them, a potential interpretation could be that receiving remittances discourages people from protesting and demonstrating. However, as far as people joining protestations, receiving remittances does not play any role in decreasing damages. While the IMF-World Bank program does not appear to significantly affect the likelihood of civil conflict, column 6 shows that being in the program significantly reduces the intensity of civil conflict, suggesting that structural reforms potentially play a role in reinforcing socio-political stability.

\footnotetext{
the number of observations drops sharply and the results could not be interpreted because of non-consistency. Additionally, results did not change when Official Development Aid and political changes were controlled for. Furthermore, since it is possible that food production sufficiency reduces countries' exposure to trade shocks, the paper crossed the shock variables with the share of agricultural production, but the results remained unchanged.

${ }^{18}$ The paper opted not to go further on theses interpretations. In fact, while the interpretation in terms of magnitude might be useful, earlier comments on the paper suggested to remove them and be more cautious on exact numbers, as sample consistency might lead to parameters that vary considerably depending on countries.
} 
Table 2. Baseline Results: Food Price Shocks and Conflicts: The Roles of Fiscal Policy and Remittances

\begin{tabular}{|c|c|c|c|c|c|c|}
\hline Model & (1) & $\begin{array}{c}\text { (2) } \\
\text { Probit } \\
\text { Civil Conflict }\end{array}$ & $\begin{array}{c}(3) \\
\text { IV Probit }\end{array}$ & $\begin{array}{c}(4) \\
\text { Probit } \\
\text { Civil Conflict }\end{array}$ & $\begin{array}{c}(5) \\
\text { IV Probit }\end{array}$ & $\begin{array}{c}(6) \\
\text { IV Tobit } \\
\text { Conflict Intensity }\end{array}$ \\
\hline Shock & $\begin{array}{l}0.604^{* *} \\
(2.35)\end{array}$ & $\begin{array}{l}-1.288 \\
(-0.51)\end{array}$ & $\begin{array}{c}4.425^{* * *} \\
(2.64)\end{array}$ & $\begin{array}{l}0.696 \\
(0.32)\end{array}$ & $\begin{array}{c}5.152^{* * *} \\
(2.71)\end{array}$ & $\begin{array}{c}8.035^{* * *} \\
(7.73)\end{array}$ \\
\hline Gov Expenditure & & $\begin{array}{c}0.00142 \\
(0.31)\end{array}$ & $\begin{array}{c}-0.000146 \\
(-0.03)\end{array}$ & & & $\begin{array}{c}-0.000744 \\
(-0.40)\end{array}$ \\
\hline Fiscal Stimuli & & & & $\begin{array}{c}0.00890 \\
(0.03)\end{array}$ & $\begin{array}{l}0.265 \\
(1.23)\end{array}$ & \\
\hline Remittances & & $\begin{array}{c}-0.0964^{*} \\
(-1.80)\end{array}$ & $\begin{array}{c}-0.0875^{* *} \\
(-1.98)\end{array}$ & $\begin{array}{l}-0.112^{*} \\
(-1.66)\end{array}$ & $\begin{array}{l}-0.0478 \\
(-1.29)\end{array}$ & $\begin{array}{c}0.00844 \\
(0.39)\end{array}$ \\
\hline $\begin{array}{l}\text { Shock*Gov } \\
\text { Expenditure }\end{array}$ & & 0.0486 & 0.0140 & & & -0.0108 \\
\hline $\begin{array}{l}\text { Shock*Fiscal } \\
\text { Stimuli }\end{array}$ & & $(1.61)$ & $(0.38)$ & $-2.721^{* *}$ & -2.134 & $(-0.55)$ \\
\hline $\begin{array}{l}\text { Shock*Remittan } \\
\text { ces }\end{array}$ & & $-0.483^{* *}$ & $-0.509^{* * *}$ & $\begin{array}{c}(-2.28) \\
-0.487^{* * *}\end{array}$ & $\begin{array}{l}(-1.58) \\
-0.324^{* *}\end{array}$ & -0.123 \\
\hline GDPgrowth & & $(-2.07)$ & $\begin{array}{l}(-3.17) \\
-1.013 \\
(-0.11)\end{array}$ & $(-3.11)$ & $\begin{array}{l}(-2.49) \\
-3.427 \\
(-0.34)\end{array}$ & $\begin{array}{l}(-0.81) \\
6.542 \\
(1.64)\end{array}$ \\
\hline $\begin{array}{l}\text { IMF-World } \\
\text { Bank Program }\end{array}$ & & & -0.0239 & & -0.203 & $-0.866^{* *}$ \\
\hline Financial Crisis & & & $\begin{array}{l}(-0.05) \\
-0.265 \\
(-1.06)\end{array}$ & & $\begin{array}{l}(-0.44) \\
-0.184 \\
(-0.86)\end{array}$ & $\begin{array}{l}(-2.37) \\
0.0555 \\
(0.27)\end{array}$ \\
\hline _cons & $\begin{array}{l}0.728 \\
(5.51) \\
\end{array}$ & $\begin{array}{c}2.921^{* * *} \\
(4.47) \\
\end{array}$ & $\begin{array}{l}1.206^{* *} \\
(2.14)\end{array}$ & $\begin{array}{l}4.051^{* * *} \\
(3.20)\end{array}$ & $\begin{array}{l}0.738^{*} \\
(1.91) \\
\end{array}$ & $\begin{array}{l}-0.259 \\
(-0.60) \\
\end{array}$ \\
\hline $\begin{array}{l}\text { Number of obs } \\
\text { Number of countries }\end{array}$ & 594 & $\begin{array}{c}351 \\
44\end{array}$ & 344 & $\begin{array}{c}411 \\
57\end{array}$ & 398 & 383 \\
\hline Chi_squared (P value) & & & 0.83 & & 0.70 & 0.22 \\
\hline
\end{tabular}

Notes: These results are obtained using Probit, IV Probit and IV Tobit models. Wald tests of exogeneity are reported at the bottom of the table. Standard errors are clustered at the country level. All regressions contain year fixed effects. The results also remain unchanged when the dependent variables are the number of conflicts during the year. $t$ statistics in parentheses ${ }^{*} p<0.10,{ }^{* *} p<0.05,{ }^{* * *} p<0.01$.

\section{b) Heterogeneity Analyses.}

In this section, the paper successively assesses (i) whether the results still hold when regional dummies are considered in the regressions; (ii) whether the results are the same in lower-income countries and higher-income countries; and (iii) whether the results do not differ for countries which lower access to private credit.

Regional Heterogeneities. The sample contains data from almost all developing countries in the world. Since all the regions (continents) might not have the same characteristics, the paper aims to see whether the results remain unchanged when continental unobservable characteristics are taken into consideration. The best way would have been to run regressions for each regional subsample separately. However, as splitting the sample by regional sub-sample will not give robust results because of the poor consistency on data (poor number of observations for some regions, the paper prefers to include the continental dummies in the regressions while keeping other controls. The results are given in table 3. While almost all variables maintain the same statistical significance as when the regional dummies were not considered, the paper finds that African 
countries are less likely to experience government crises than other continents. However, caution is required when considering this result, as most politically unstable African countries considered are poorly represented in the sample. For example, Central African Republic, Libya, North Sudan, Somalia, South Sudan and Zimbabwe are not considered. Chad, Cote d'Ivoire (4) and Democratic Republic of the Congo respectively have 7, 4 and 8 observations through the 33 years covered.

Heterogeneity Regarding Income Level. The intuition is that in countries with higher levels of income, people are less likely to join demonstrations in times of food crises, as they have more means of purchasing food in times of food crises. Hence, fiscal policy would less likely be implemented with the aim of stabilization in this context, while the reverse might be true when people have less income. The sample is split into two subsamples. While the first subsample contains countries whose income per capita lies below $\$ 35,599.5$ (constant base 2011), which is the median value, the second subsample contains countries whose per capita income lies above that value. The results are displayed on table 4 , where columns 1 and 3 clearly indicate that food price shocks significantly increase the likelihood of civil conflict in both lower and higher income countries. However, the coefficient in the lower income sub-sample is more than double that of the higher income sub-sample. While these coefficients cannot be interpreted directly since they are not marginal effects, this result is informative and tends to support the intuition according to which higher income countries are less likely to experience socio-political instability in times of food price shocks. The results regarding government crises in columns 2 and 4 almost go in the same direction, as columns 1 and 3 tend to support the idea that food price shocks significantly increase the likelihood of government crises only in countries with lower income per capita. 
Table 3. Food price shocks and socio-political instability: geographical heterogeneities

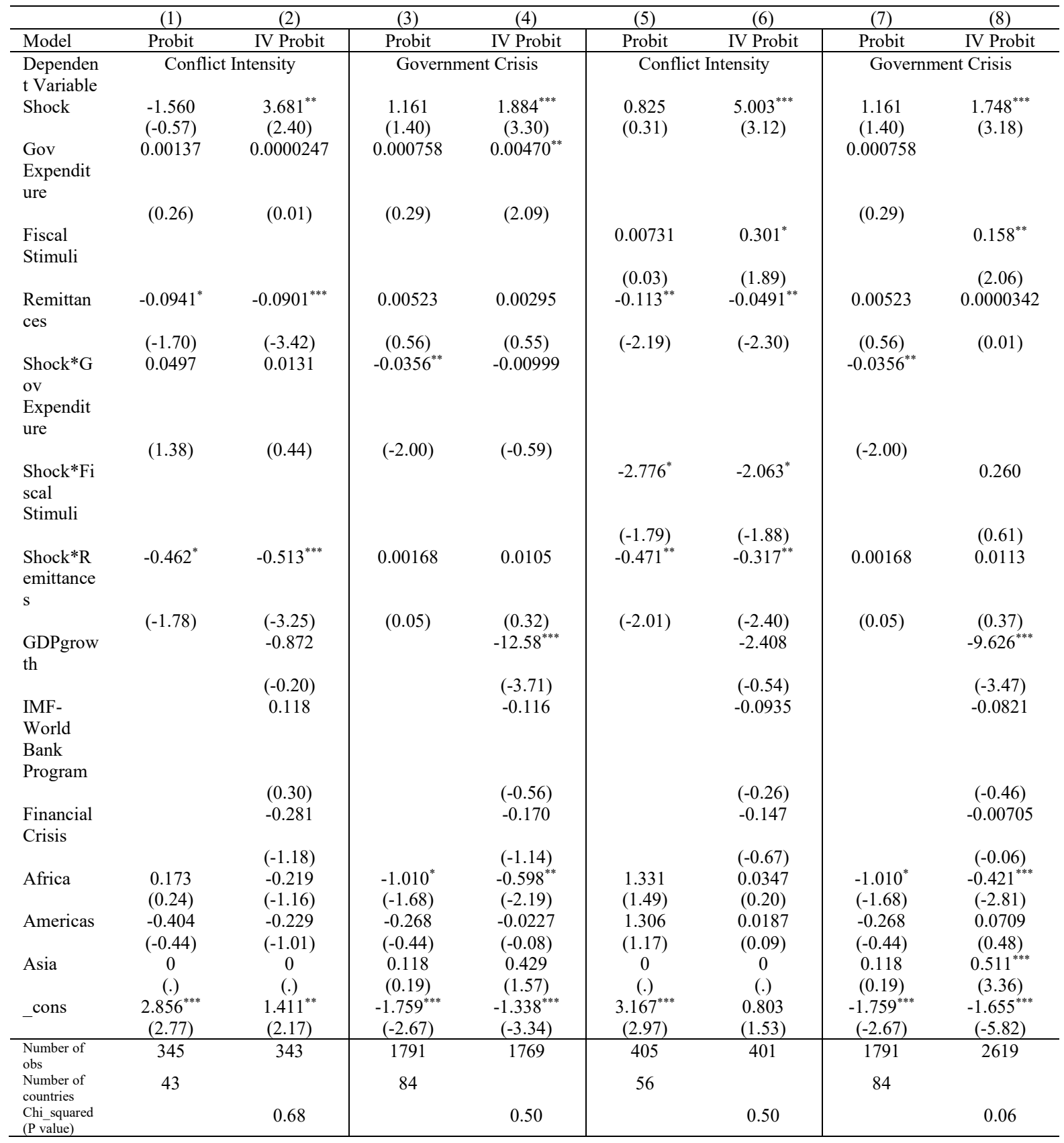

Notes: These results are obtained using Probit and IV Probit models. Wald tests of exogeneity are reported at the bottom of the table. The results also remain unchanged when the dependent variables are the number of conflicts during the year. Europe and Oceania dummies are due to collinearity .t statistics in parentheses ${ }^{*} p<0.10,{ }^{* *} p<0.05,{ }^{* * *} p<0.01$. 
The countercyclical effect of remittances on civil conflict shows significant results only in countries with lower incomes. Fiscal policy also seems to dampen the positive effect of food price shocks on the likelihood of civil conflict and government crises, but the results depend on the fiscal policy variable considered.

Heterogeneity with regard to Access to Private Credit. The paper also considers that there could be some differences in the results regarding the extent to which households have access to financial services. The paper hypothesizes that in countries where households have more access to private credit, they are certainly less vulnerable to hunger and less likely to protest following food crisis episodes, as they are able to borrow in order to access food. Thus, countercyclical fiscal policy would barely work in this situation, while the reverse might be true in countries with higher access to private credit. The results are presented in table 5.

Table 4. Food Price Shocks and Political Instability: The Role of Fiscal Policy by Level of

\begin{tabular}{|c|c|c|c|c|}
\hline \multicolumn{5}{|c|}{ Income } \\
\hline & $(1)$ & (2) & (3) & (4) \\
\hline Model & \multicolumn{4}{|c|}{ Probit } \\
\hline Dependent Variable & Civil Conflict & Government Crisis & Civil Conflict & Government Crisis \\
\hline Sample & \multicolumn{2}{|c|}{ Lower Income } & \multicolumn{2}{|c|}{ Higher Income } \\
\hline Shock & $\begin{array}{c}8.723^{* * *} \\
(2.73)\end{array}$ & $\begin{array}{c}5.511^{* * *} \\
(4.45)\end{array}$ & $\begin{array}{l}4.521^{*} \\
(1.95)\end{array}$ & $\begin{array}{c}0.363 \\
(0.29)\end{array}$ \\
\hline Gov Expenditure & & $\begin{array}{c}-0.00172 \\
(-0.45)\end{array}$ & & $\begin{array}{c}0.00103 \\
(0.52)\end{array}$ \\
\hline Fiscal Stimuli & $\begin{array}{c}0.460 \\
(1.07)\end{array}$ & & $\begin{array}{l}0.137 \\
(0.68)\end{array}$ & \\
\hline Remittances & $\begin{array}{c}-0.00552 \\
(-0.16)\end{array}$ & $\begin{array}{c}-0.00514 \\
(-0.57)\end{array}$ & $\begin{array}{l}-0.157^{*} \\
(-1.80)\end{array}$ & $\begin{array}{c}0.0478^{* * *} \\
(2.79)\end{array}$ \\
\hline Shock*Gov & & $-0.0594^{* *}$ & & -0.0204 \\
\hline Expenditure & & $(-2.29)$ & & $(-1.45)$ \\
\hline Shock*Fiscal Stimuli & $\begin{array}{l}-1.859 \\
(-1.25)\end{array}$ & & $\begin{array}{c}-3.150^{* *} \\
(-2.15)\end{array}$ & \\
\hline Shock*Remittances & $\begin{array}{c}-0.458^{*} \\
(-1.92)\end{array}$ & $\begin{array}{c}-0.00427 \\
(-0.08)\end{array}$ & $\begin{array}{l}-0.223 \\
(-0.96)\end{array}$ & $\begin{array}{c}0.0248 \\
(0.55)\end{array}$ \\
\hline Financial Crisis & $\begin{array}{l}-0.316 \\
(-1.00)\end{array}$ & $\begin{array}{l}0.187 \\
(1.03)\end{array}$ & $\begin{array}{l}0.299 \\
(0.72)\end{array}$ & $\begin{array}{l}0.102 \\
(0.56)\end{array}$ \\
\hline _cons & $\begin{array}{l}-0.746 \\
(-0.76)\end{array}$ & $\begin{array}{c}-1.805^{* * *} \\
(-5.09)\end{array}$ & $\begin{array}{l}0.618 \\
(1.04)\end{array}$ & $\begin{array}{c}-2.012^{* * *} \\
(-6.45)\end{array}$ \\
\hline Number of obs & 159 & 733 & 202 & 976 \\
\hline
\end{tabular}

These results are obtained using a Maximum Likelihood Tobit model. "Lower Income" means observations with GDP less than \$ 35,599.5 (constant base 2011) (Median GDP in the sample), while "Higher Income" refers to those countries above that median. Standard errors are clustered at the country level. All regressions contain year fixed effects. The results also remain unchanged when the dependent variables are the number of civil conflicts during the year. $t$ statistics in parentheses ${ }^{*} p<0.10,{ }^{* *} p<0.05,{ }^{* * *} p<0.01$.

Poor credit access countries are those whose level of private credit lies below $22 \%$ (the median value), while those lying above are included in the high credit access sample.

While results clearly establish that food price shocks positively affect the likelihood of civil conflicts and government crises in both samples, results are more statistically significant in countries with lower access to financial private credit. With regard to fiscal policy, the results are rather mixed and sometime contradictory (column 1, as the paper was expecting fiscal policy to negatively affect the dependent variable). Results for remittances also seem very mixed, with remittances reducing the likelihood of civil conflict only in higher credit access countries, which could be suggesting that households in these countries have enough private 
credit possibilities to resort to when needed. The mitigating role of remittances also seem to be significant in column 1, but this significant vanishes in column 2. Surprisingly, results in column 6 show a strongly significant and positive effect of remittances in times of food crises on the likelihood of government crises in countries with higher credit access. This result tends to be consistent with the results in column 4 of table 4 , where remittances significantly increase the likelihood of government crises. One interpretation of this could be the possibility of considering that in higher credit access countries, remittances are greater than the amount that would have been useful in helping households meet their needs, so they use the reminder to finance government crises. 
Table 5. Food Price Shocks and Political Instability: by Level of Private Credit Access

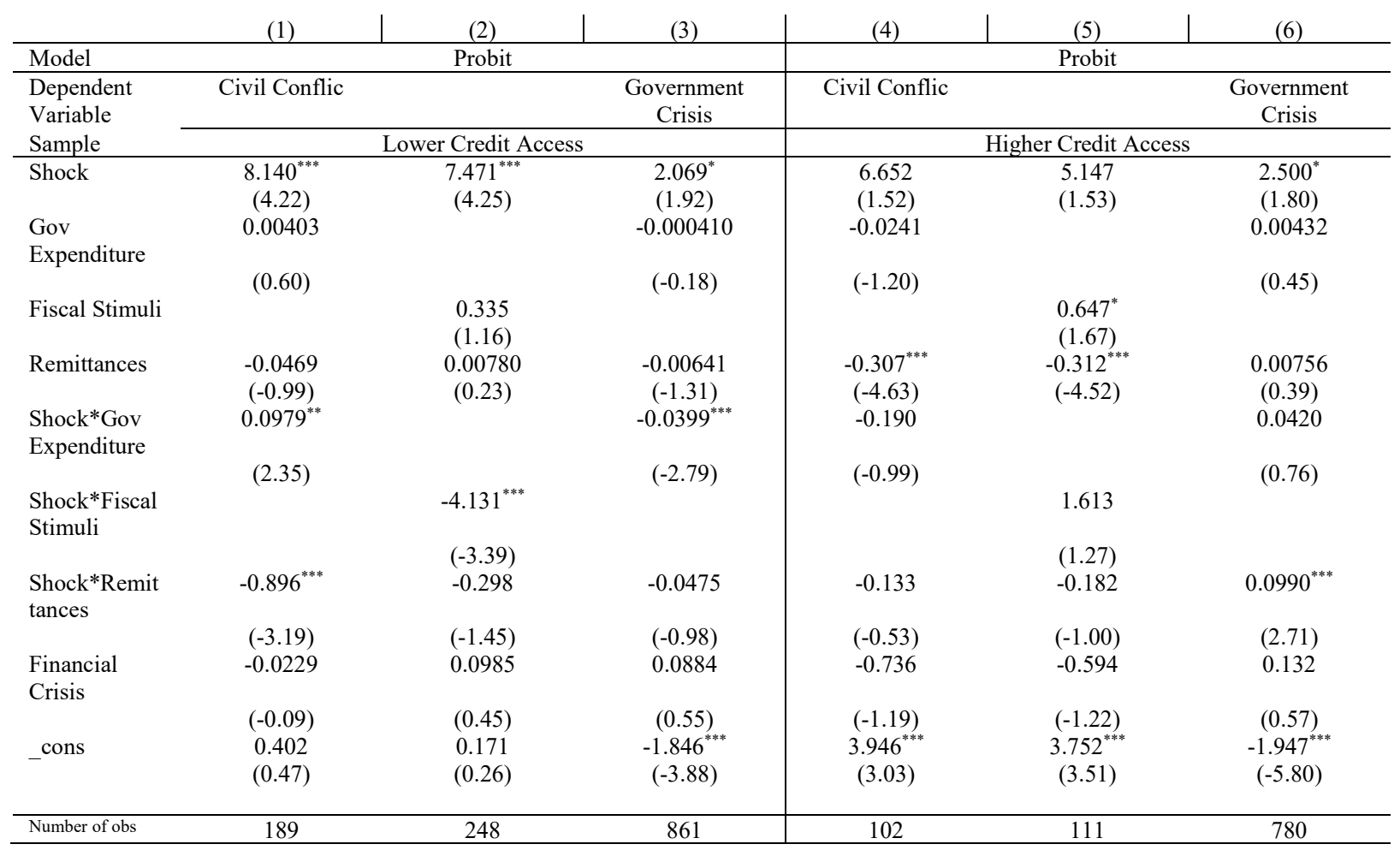

Notes: These results are obtained using Probit model. "Lower credit access" means private credit levels that are lesser than $22 \%$ of GDP (Median private credit in the sample), while "Higher credit access" are those above that Median. Standard errors are clustered at the country level. All regressions contain year fixed effects. The results also remain unchanged when the dependent variables are the number of civil conflicts during the year. These results remain unchanged when the IMF-World Bank dummy was included. $t$ statistics in parentheses ${ }^{*} p<$ $0.10,{ }^{* *} p<0.05,{ }^{* * *} p<0.01$.

\section{c) Robustness checks.}

In this section, the paper explores the role of fiscal policy and remittances in times of food price shocks considering other variables of price shocks and socio-political instability.

Using the Frequency of Positive Food Price Shocks. The research hypothesizes that households are more hampered by positive import food price shocks. Hence, in this section, the paper uses the frequency of positive food price shocks in each of four successive years as the shock variable. The results are presented in table 6. Columns 1 to 6 support the fact that the more positive food price shocks are observed, the more likely civil conflict will occur. According to these results, while remittances alone do not appear to significantly reduce the probability of civil conflict, all the regressions robustly support the idea that remittances dampen the effect of positive food price shocks on the probability of civil conflicts.

However, the paper does not see any evidence of the effect of fiscal policy on the probability of civil conflict. 
Table 6. Positive Food Price Shocks and Civil Conflicts: The Roles of Fiscal Policies and Remittances

\begin{tabular}{|c|c|c|c|c|c|c|}
\hline & (1) & (2) & (3) & (4) & (5) & (6) \\
\hline Model & & & IV Probit & \multicolumn{2}{|c|}{ Probit } & IV Probit \\
\hline $\begin{array}{l}\text { Dependent } \\
\text { Variable } \\
\end{array}$ & & Civil Conflict & & & ivil Confli & \\
\hline $\begin{array}{l}\text { Positive_Shock } \\
\text { Gov Expenditure }\end{array}$ & $\begin{array}{c}0.235^{* * *} \\
(3.38) \\
-0.00172 \\
(-0.50)\end{array}$ & $\begin{array}{c}0.342^{* * *} \\
(4.09) \\
-0.00858^{*} \\
(-1.77)\end{array}$ & $\begin{array}{c}0.311^{* * *} \\
(3.94) \\
-0.00231 \\
(-0.56)\end{array}$ & $\begin{array}{c}0.202^{* * *} \\
(2.96)\end{array}$ & $\begin{array}{c}0.337^{* * * *} \\
(3.42)\end{array}$ & $\begin{array}{l}0.205^{* *} \\
(2.57)\end{array}$ \\
\hline Fiscal Stimuli & & & & $\begin{array}{c}-0.0199 \\
(-0.10)\end{array}$ & $\begin{array}{c}0.0674 \\
(0.23)\end{array}$ & $\begin{array}{l}0.240 \\
(0.69)\end{array}$ \\
\hline Remittances & $\begin{array}{c}-0.0145 \\
(-0.46)\end{array}$ & $\begin{array}{c}0.0434 \\
(1.43)\end{array}$ & $\begin{array}{c}0.0184 \\
(0.88)\end{array}$ & $\begin{array}{l}-0.0401 \\
(-0.97)\end{array}$ & $\begin{array}{c}0.0249 \\
(0.86)\end{array}$ & $\begin{array}{c}0.00770 \\
(0.37)\end{array}$ \\
\hline $\begin{array}{l}\text { Positive_Shock*G } \\
\text { ov Expenditure }\end{array}$ & & $\begin{array}{c}0.00526 \\
(1.34)\end{array}$ & $\begin{array}{c}0.000887 \\
(0.27)\end{array}$ & & & \\
\hline $\begin{array}{l}\text { Positive } \\
\text { Shock*Fiscal } \\
\text { Stimuli }\end{array}$ & & & & & -0.0405 & -0.0383 \\
\hline $\begin{array}{l}\text { Positive } \\
\text { Shock*Remittanc } \\
\text { es }\end{array}$ & & $-0.0479^{* * *}$ & $-0.0388^{* * *}$ & & $\begin{array}{c}(-0.35) \\
-0.0384^{* *}\end{array}$ & $\begin{array}{l}(-0.37) \\
-0.0200\end{array}$ \\
\hline GDPgrowth & & $(-2.60)$ & $\begin{array}{c}(-2.90) \\
1.758 \\
(0.29)\end{array}$ & & $(-1.98)$ & $\begin{array}{l}(-1.56) \\
-0.747 \\
(-0.14)\end{array}$ \\
\hline $\begin{array}{l}\text { IMF-World Bank } \\
\text { Program }\end{array}$ & & & 0.0458 & & & 0.0371 \\
\hline Financial Crisis & & & $\begin{array}{c}(0.15) \\
-0.413^{*} \\
(-1.72)\end{array}$ & & & $\begin{array}{l}(0.13) \\
-0.267 \\
(-1.26)\end{array}$ \\
\hline _cons & $\begin{array}{c}0.860^{* * * *} \\
(2.62)\end{array}$ & $\begin{array}{c}0.709^{* *} \\
(2.30)\end{array}$ & $\begin{array}{l}0.0733 \\
(0.35) \\
\end{array}$ & $\begin{array}{c}1.241^{* * *} \\
(2.98)\end{array}$ & $\begin{array}{c}0.989^{* * *} \\
(2.68)\end{array}$ & $\begin{array}{l}0.214 \\
(0.88)\end{array}$ \\
\hline $\begin{array}{l}\text { Number of obs } \\
\text { Number of } \\
\text { countries }\end{array}$ & $\begin{array}{c}406 \\
52\end{array}$ & $\begin{array}{c}406 \\
52\end{array}$ & 376 & $\begin{array}{c}463 \\
66\end{array}$ & $\begin{array}{c}463 \\
66\end{array}$ & 425 \\
\hline $\begin{array}{l}\text { Chi_squared (P } \\
\text { value) }\end{array}$ & & & 0.957 & & & 0.790 \\
\hline
\end{tabular}

Notes: These results are obtained using Probit and IV Probit models. Wald tests of exogeneity are reported at the bottom of the table. Standards errors and clustered at the country level. All regressions contain year fixed effects. The results also remain unchanged when the dependent variables are the number of conflicts during the year. $t$ statistics in parentheses ${ }^{*} p<0.10,{ }^{* *} p<0.05,{ }^{* * *} p<0.01$.

Using other socio-political instability variables to investigate whether the results remain the same with other socio-political instability variables, the research also assesses the impact of food price shocks on the likelihood of expropriations when fiscal policy and remittances are involved. The paper runs the same regressions as in table 3 by considering the likelihood of expropriations as the dependent variable. In the results recorded in table 7 (appendix), food price shocks generally affect the likelihood of expropriation positively, even if its coefficients are only significant in columns 4 to 6 when fiscal stimuli is used as the fiscal variable. Moreover, while remittances generally seem to mitigate the adverse impact of food price shocks on the likelihood of expropriations (interaction between food price shocks and remittances is generally positive and significant), there is no evidence that fiscal policy plays a mitigating role. This would seem to be consistent with the previous results for other sociopolitical instability variables. Furthermore, the research also introduced the first lag of thedependent variables, as well as the two first lags of price shock variables to check whether there was any issue of reverse causality. The results obtained (available upon request) remained almost the same as those obtained above, with the exception that cumulative effects of food price shocks lead to a higher likelihood of expropriation. The paper also checked whether large food price shocks matter by controlling the regression with a standard deviation of food price shocks, but that did not provide any additional results for the study. 
Lastly, the paper runs additional instrumental regressions where both GDP per capita growth and remittances are considered as endogenous variables. Remittances could be affected by political instability, as relatives abroad could be more prone to remit with the aim of protecting their relatives in the country. Table 8 show the results obtained using both IV Tobit and two-stage least square IV. These results are very similar to those obtained using IV Probit and IV Tobit, with the slight difference that the estimated coefficients of GDP growth and the IMF-World Bank program often significantly and negatively, meaning that an increase in GDP growth and structural reforms potentially have a positive impact on sociopolitical stability. ${ }^{19}$

\section{CONCLUSION}

This paper aims to assess the effect of remittances and fiscal policy on socio-political instability in times of import food price shocks. It uses a large sample of developing countries over the period 1980-2012. The research uses two measures of fiscal policy that might most likely be used by governments when trying to handle socio-political instability risks in times of food crises. Since the paper aims to emphasize the vulnerability consequences of food price shocks on households, it only considers import food price shocks. The paper calls on the Probit and maximum likelihood Tobit models that are more suitable given the structure of the dependent variables (qualitative variables and limited variables with a concentration of observations on some modalities). The IV versions of Probit and Maximum Likelihood Tobit models, as well as the two-stage least square instrumental variables are used to address endogeneity.

The papers find that positive food price shocks significantly increase the probability of civil conflict, government crises, and expropriations. Conflict intensity is likely to be more significant in times of food price shocks, and these effects seem to be more important in countries with lower access (less than 22\% of GDP which is the median level of private credit in the sample) to private credit and lower income levels (less than $\$ 35,599$, constantprice in base year 2011). Fortunately, remittances dampen the adverse effects of positive food price shocks on the probability of civil conflicts and expropriations. Unfortunately, the results regarding the mitigating role of fiscal policy in socio-political instability across the entire sample are mixed and depend on the variables and estimator considered. The results nevertheless tend to highlight the fact that fiscal policy mitigates the adverse effects of food price shocks on the likelihood of socio-political instability in countries with lower access to private credit. The results seem to be consistent when additional controls are added and when dummies are included. The research suspects that the barely significant effect of the mitigating role of fiscal policy is the signal that fiscal responses are insufficient to yield a significant effect.

As for implications, the findings thus underlined the adverse effect of import food price shocks on political instability, which is in line with the findings of Arezki and Bruckner (2011) according to whom export food price shocks increase the likelihood of political

\footnotetext{
${ }^{19}$ The results obtained using the two-stage least square IV model have a smaller standard deviation. However, since the dependent variable is limited, the paper keeps the estimates generated using the IV Tobit as the baseline.
} 
instability in developing countries. As the result supports the fact that remittances play a vital role in dampening the negative impact of import food price shocks on socio-political instability, the paper strongly recommends measures to favor remittance inflows in developing countries: these measures could consider the reduction of transfers costs. While the paper recommends that fiscal authorities take more countercyclical measures targeting low-income households and other vulnerable people in times of import food price shocks, any policy trying to limit developing countries' vulnerability to import food price shocks are highly recommended. 


\section{REFERENCES}

Agnello, Luca, Vitor Castro, João Tovar Jalles, and Ricardo M. Sousa, 2017, "Income Inequality, Fiscal Stimuli and Political (in) Stability", International Tax and Public Finance, 24(3): 484-511.

Agnello, Luca, and Ricardo M. Sousa, 2009, "The Determinants of Public Deficit Volatility"

Aguirre, Alvaro, 2016, "Fiscal Policy and Civil Conflict in Africa", Journal of African Economies, 25(4): 614-636.

Aisen, Ari, and Francisco José Veiga, 2013, "How Does Political Instability Affect Economic Growth?", European Journal of Political Economy, 29: 151-167.

Annett, Anthony, 2000, "Social Fractionalization, Political Instability, and the Size of Government".

Arezki, Mr Rabah, and Markus Bruckner, 2011, "Food Prices and Political Instability", International Monetary Fund, Working Paper 11-62.

Barnett, Jon, 2003, "Security and Climate Change", Global Environmental Change ,13(1): $7-17$.

Barro, Robert J., and Xavier Sala-i-Martin, 1995, "Technological Diffusion, Convergence, and Growth", National Bureau of Economic Research.

Baser, Bahar, and Ashok Swain, 2008, "Diasporas as Peacemakers: Third Party Mediation in Homeland Conflicts", International Journal on World Peace, 7-28.

Bellemare, Marc F., 2015, "Rising Food Prices, Food Price Volatility, and Social Unrest", American Journal of Agricultural Economics, 97(1): 1-21.

Besley, Timothy J., and Torsten Persson, 2008, "The Incidence of Civil War: Theory and Evidence", National Bureau of Economic Research.

Blanchard, Olivier Jean, 1990, "Suggestions for a New Set of Fiscal Indicators".

Brückner, Markus, and Antonio Ciccone, 2010, "International Commodity Prices, Growth and the Outbreak of Civil War in Sub-Saharan Africa", The Economic Journal, 120(544): 519-534.

Chami, Ralph, Dalia S. Hakura, and Peter J. Montiel, 2012, "Do Worker Remittances Reduce Output Volatility in Developing Countries?", Journal of Globalization and Development 3(1). 
Change, Intergovernmental Panel On Climate, 2014

IPCC. Climate Change.

Collier, Paul, and Jan Dehn, 2001, "Aid, Shocks, and Growth" World Bank Publications, (Vol. 2688).

Collier, Paul, and Anke Hoeffler,2004, "Greed and Grievance in Civil War", Oxford Economic Papers,56(4): 563-595.

Combes, Jean-Louis, and Christian Ebeke, 2011, "Remittances and Household Consumption Instability in Developing Countries", World Development, 39(7): 1076-1089.

Combes, Jean-Louis, Christian Hubert Ebeke, Sabine Mireille Ntsama Etoundi, and Thierry Urbain Yogo, 2014, "Are Remittances and Foreign Aid a Hedge against Food Price Shocks in Developing Countries?", World Development, 54: 81-98.

Craigwell, Roland, Mahalia Jackman, and Winston Moore, 2010, "Economic Volatility and Remittances", International Journal of Development Issues, 9(1): 25-42.

Deaton, Angus, and Ronald I. Miller, 1995, "International Commodity Prices, Macroeconomic Performance, and Politics in Sub-Saharan Africa", International Finance Section, Department of Economics, Princeton University Princeton, NJ.

Devereux, Michael B., and Jean-Francois Wen, 1998, "Political Instability, Capital Taxation, and Growth", European Economic Review, 42(9): 1635-1651.

Draman, Abdul-Rasheed, David M. Malone, and Mats Berdal, 2000, "Greed \& Grievance: Economic Agendas in Civil Wars", International Journal,55(4): 682.

Dreher, Axel, Jan-Egbert Sturm, and James Raymond Vreeland, 2009, "Development Aid and International Politics: Does Membership on the UN Security Council Influence World Bank Decisions?", Journal of Development Economics,88(1): 1-18.

Ebeke, Christian, and Jean-Louis Combes, 2013, "Do Remittances Dampen the Effect of Natural Disasters on Output Growth Volatility in Developing Countries?", Applied Economics 45(16): 2241-2254.

FAO, IFAD, OECD IMF, and WFP UNCTAD, 2011, The World Bank, the WTO, IFPRI and the UN HLTF," Price Volatility in Food and Agricultural Markets: Policy Responses", Policy Report to the G20 Group of Nations.

Fatas, Antonio, and Ilian Mihov, 2003, "On Constraining Fiscal Policy Discretion in EMU", Oxford Review of Economic Policy 19(1): 112-131.

Finlay, Keith, and Leandro M. Magnusson, 2009, "Implementing Weak-Instrument Robust Tests for a General Class of Instrumental-Variables Models", Stata Journal 9(3): 398. 
Greene, William H. 2012, “Econometric Analysis, 71e.” Stern School of Business, New York University . N.d.

Gries, T., \& Meierrieks, D. 2013, " Do banking crises cause terrorism?", . Economics Letters, 119(3), 321-324.

Hendrix, C.; Brinkman, H.-J., 2013, "Food insecurity and conflict dynamics: Causal linkages and complex feedbacks. Stability", International Journal of Security and Development, 2(2).

Gupta, Abhijit Sen, 2007, "Determinants of Tax Revenue Efforts in Developing Countries". International Monetary Fund, Working Paper, 7-184.

Laeven, M. L., \& Valencia, M. F, 2018, " Systemic banking crises revisited.". International Monetary Fund.

Maddala, Gangadharrao Soundaryarao, and Kajal Lahiri, 1992, "Introduction to Econometrics", Macmillan New York, vol.2.

Miranda, Alfonso, and Sophia Rabe-Hesketh, 2006, "Maximum Likelihood Estimation of Endogenous Switching and Sample Selection Models for Binary, Ordinal, and Count Variables." Stata Journal, 6(3): 1-24.

Ortiz, Isabel, and Matthew Cummins, 2012, "A Recovery for All: Rethinking SocioEconomic Policies for Children and Poor Households."

Pinstrup-Andersen, Per, and Satoru Shimokawa, 2008, "Do Poverty and Poor Health and Nutrition Increase the Risk of Armed Conflict Onset?" Food Policy,33(6): 513520 .

Raleigh, Clionadh, Hyun Jin Choi, and Dominic Kniveton, 2015, "The Devil Is in the Details: An Investigation of the Relationships between Conflict, Food Price and Climate across Africa." Global Environmental Change, 32: 187-199.

Ravn, Morten O., and Harald Uhlig, 2002, "On Adjusting the Hodrick-Prescott Filter for the Frequency of Observations." Review of Economics and Statistics, 84(2): 371-376.

Smit, Barry, and Mark W. Skinner, 2002, "Adaptation Options in Agriculture to Climate Change: A Typology." Mitigation and Adaptation Strategies for Global Change, 7(1): 85-114.

Smith, Lawrence D., 1997,"Price Stabilization, Liberalization and Food Security: Conflicts and Resolutions?" Food Policy, 22(5): 379-392. 
Smith, Todd Graham, 2014, "Feeding Unrest: Disentangling the Causal Relationship between Food Price Shocks and Sociopolitical Conflict in Urban Africa." Journal of Peace Research, 51(6): 679-695.

Sobek, David, and Charles Boehmer, 2009, "If They Only Had Cake: The Effect of Food Supply on Civil War Onset, 1960-1999" The Selected Works of Charles Boehmer: 2 .

Wooldrige, J. H., 2002.,"Econometric Analysis of Cross Section and Panel Data" 2rd Edition, Cambridge, MA, MIT Press.

Ziesemer, Thomas HW, 2011, "Developing Countries' Net-Migration: The Impact of Economic Opportunities, Disasters, Conflicts, and Political Instability." International Economic Journal, 25(3): 373-386. 


\section{Appendix}

Figure 3. Patterns of Food Commodity Prices from 1980 to 2012

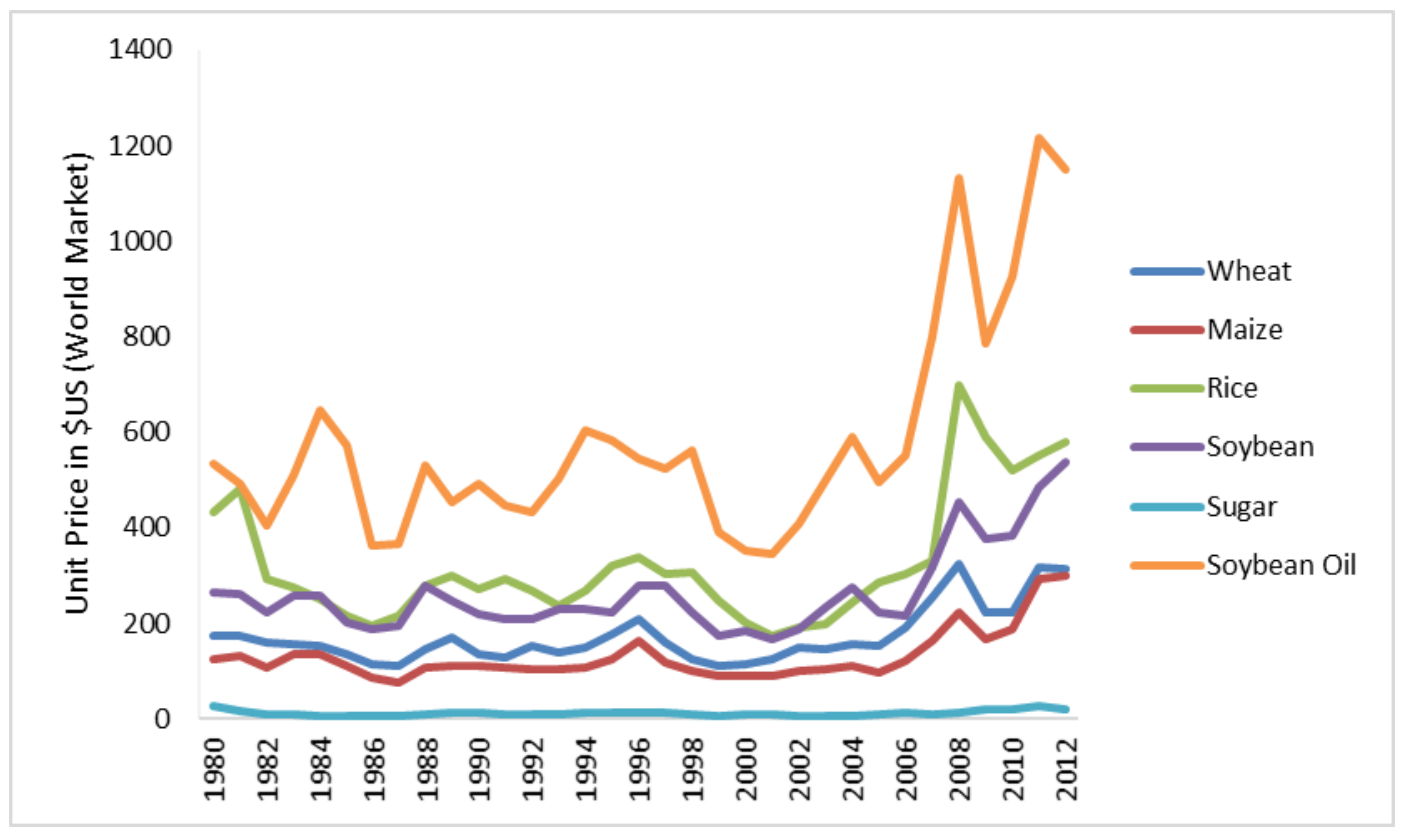

Note: World prices of the six staple foods considered in this research. Data are from IMF WEO database.

Figure 4. Socio-political instability with Fiscal stimuli versus no Fiscal Stimuli

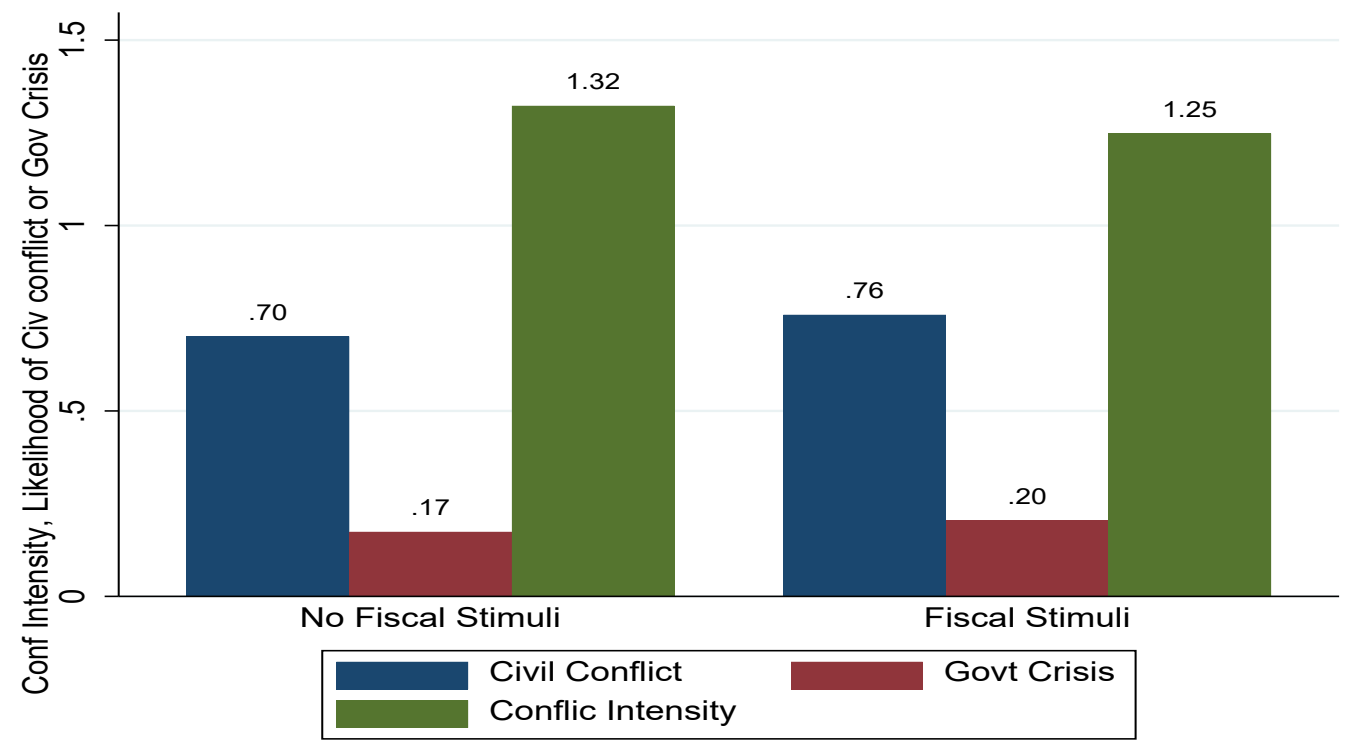

Source: Authors, using data from Prio/Upsala, Cross-National Time-Series Data Archive (CNTS) and World Bank Indicators. On the $\mathrm{x}$-axis, Fiscal stimuli refers to the situations where there was at least one fiscal stimuli. 
Figure 5. Remittances and Food Price Shocks

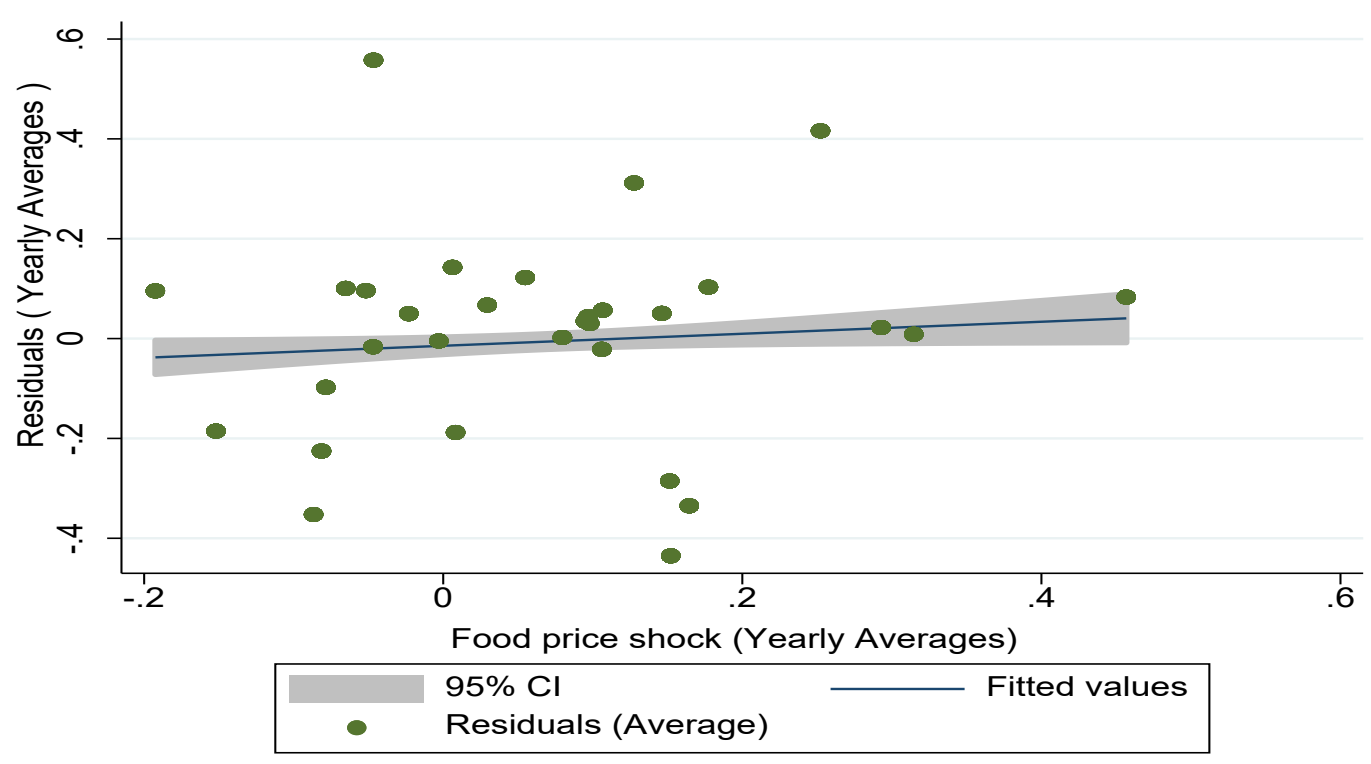

Source: Authors, using IMF WEO, FAO Statistics and World Bank Indicators. The residuals are extracted from a regression of food price shock variables on net personal received remittances. The figures represent the yearly averages of each variable. 
Table 7. Food Price Shocks and Expropriations: The Roles of Remittances and Fiscal Policy

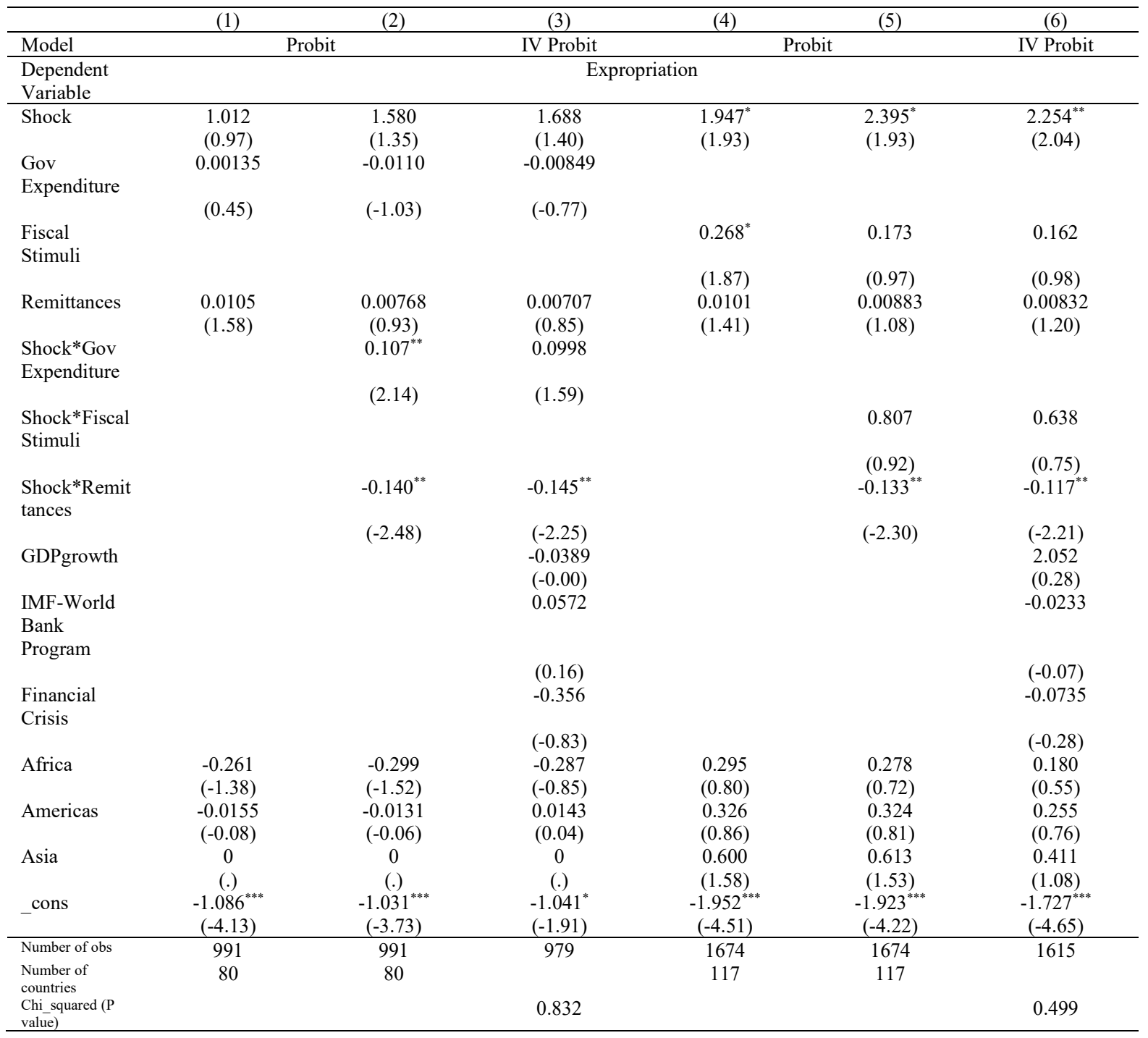

Notes: These results are obtained using Probit and IV Tobit models. Wald tests of exogeneity are reported at the bottom of the table. Standard errors are clustered at the country level. All regressions contain year fixed effects. The results also remain unchanged when the dependent variables are the number of conflicts during the year. Europe and Oceania dummies are dropped as values are considered as the references in the regional variable as references. $t$ statistics in parentheses ${ }^{*} p<0.10,{ }^{* *} p<0.05,{ }^{* * *} p<0.01$. 
Table 8: Food Price shocks and instability: Additional Robustness Checks

\begin{tabular}{|c|c|c|c|c|c|c|c|c|}
\hline & (1) & (2) & (3) & (4) & (5) & (6) & (7) & (8) \\
\hline Model & \multicolumn{4}{|c|}{ IV Tobit } & & \multicolumn{3}{|c|}{ Two Stages IV } \\
\hline $\begin{array}{l}\text { Dependent } \\
\text { Variable }\end{array}$ & \multicolumn{2}{|c|}{ Government Crisis } & \multicolumn{2}{|c|}{ Civil Conflict } & \multicolumn{2}{|c|}{ Government Crisis } & \multicolumn{2}{|c|}{ Civil Conflict } \\
\hline Shock & $\begin{array}{c}3.321^{* * *} \\
(3.99)\end{array}$ & $\begin{array}{c}3.095^{* * *} \\
(3.58)\end{array}$ & $\begin{array}{l}1.346^{* *} \\
(2.48)\end{array}$ & $\begin{array}{c}1.967^{* * *} \\
(3.24)\end{array}$ & $\begin{array}{c}0.457^{* *} \\
(2.25)\end{array}$ & $\begin{array}{l}0.348^{* *} \\
(2.44)\end{array}$ & $\begin{array}{c}1.029^{* *} \\
(2.18)\end{array}$ & $\begin{array}{c}1.535^{* * *} \\
(3.54)\end{array}$ \\
\hline $\begin{array}{l}\text { Gov } \\
\text { Expenditur } \\
\mathrm{e}\end{array}$ & 0.00312 & & 0.000137 & & $0.000599^{*}$ & & 0.0000528 & \\
\hline $\begin{array}{l}\text { Fiscal } \\
\text { Stimuli }\end{array}$ & $(0.96)$ & $0.227^{*}$ & $(0.08)$ & $0.126^{*}$ & $(1.75)$ & 0.0229 & $(0.05)$ & 0.0930 \\
\hline & & (1.81) & & (1.84) & & (1.11) & & $(1.34)$ \\
\hline Remittance & 0.00385 & 0.0000142 & $-0.0317^{* * *}$ & $-0.0209^{* *}$ & 0.000409 & 0.000150 & $-0.0242^{*}$ & -0.0164 \\
\hline & $(0.50)$ & $(0.00)$ & $(-2.93)$ & $(-2.15)$ & $(0.44)$ & $(0.17)$ & $(-1.76)$ & $(-1.35)$ \\
\hline $\begin{array}{l}\text { Shock*Gov } \\
\text { Expenditur } \\
\text { e }\end{array}$ & -0.0158 & & 0.0105 & & $-0.00449^{*}$ & & 0.00607 & \\
\hline $\begin{array}{l}\text { Shock*Fisc } \\
\text { al Stimuli }\end{array}$ & $(-0.69)$ & $\begin{array}{l}0.350 \\
(0.51)\end{array}$ & (0.89) & $\begin{array}{l}-0.863^{*} \\
(-1.88)\end{array}$ & $(-1.80)$ & $\begin{array}{l}0.0600 \\
(0.70)\end{array}$ & $(0.77)$ & $\begin{array}{c}-0.684^{* *} \\
(-2.25)\end{array}$ \\
\hline $\begin{array}{l}\text { Shock*Re } \\
\text { mittances }\end{array}$ & $\begin{array}{l}0.0468 \\
(0.98)\end{array}$ & $\begin{array}{l}0.0379 \\
(0.81)\end{array}$ & $\begin{array}{c}-0.160^{* *} \\
(-2.49)\end{array}$ & $\begin{array}{c}-0.140^{* *} \\
(-2.24)\end{array}$ & $\begin{array}{c}0.00595 \\
(0.72)\end{array}$ & $\begin{array}{c}0.00477 \\
(0.71)\end{array}$ & $\begin{array}{c}-0.113^{* *} \\
(-2.21)\end{array}$ & $\begin{array}{c}-0.0983^{* *} \\
(-2.08)\end{array}$ \\
\hline $\begin{array}{l}\text { GDPgrowt } \\
\mathrm{h}\end{array}$ & $-10.26^{*}$ & $-8.406^{*}$ & -1.262 & -2.779 & $-1.096^{*}$ & -0.746 & -0.442 & -1.092 \\
\hline & $(-1.78)$ & $(-1.80)$ & $(-0.56)$ & $(-1.12)$ & $(-1.67)$ & $(-1.53)$ & $(-0.24)$ & $(-0.60)$ \\
\hline $\begin{array}{l}\text { IMF-World } \\
\text { Bank } \\
\text { Program }\end{array}$ & $-0.540^{*}$ & $-0.458^{*}$ & -0.0133 & -0.0540 & $-0.0563^{*}$ & $-0.0455^{*}$ & -0.0169 & -0.0566 \\
\hline & $(-1.75)$ & $(-1.65)$ & $(-0.09)$ & $(-0.35)$ & $(-1.80)$ & $(-1.88)$ & $(-0.16)$ & $(-0.53)$ \\
\hline Financial & -0.0232 & 0.115 & -0.129 & -0.0856 & 0.00320 & 0.0191 & -0.0922 & -0.0576 \\
\hline & $(-0.10)$ & $(0.58)$ & $(-1.18)$ & $(-0.82)$ & $(0.11)$ & $(0.77)$ & $(-1.00)$ & $(-0.76)$ \\
\hline Number of obs & 1793 & 2634 & 354 & 398 & 1793 & 2634 & 354 & 398 \\
\hline $\begin{array}{l}\text { Chi_squared (P } \\
\text { value) } \\
\text { Rsquare }\end{array}$ & 0.309 & 0.373 & 0.485 & 0.233 & 0.0540 & 0.0429 & 0.126 & 0.0848 \\
\hline
\end{tabular}

Notes: These results are obtained using IV Tobit and Two-Stage least squares (2SLS) models. Wald tests of exogeneity are reported at the bottom of the table. All regressions contain year fixed effects. The results also remain unchanged when the dependent variables are the number of conflicts during the year. In these regressions, instruments include the first lag of GDP per capita growth and the first lag of net personal received remittances. $\mathrm{t}$ statistics in parentheses* $\mathrm{p}<0.10,{ }^{* *} \mathrm{p}<0.05,{ }^{* * *} \mathrm{p}<0.01$. 
Table 9. Variables, Definitions and Sources

\begin{tabular}{|c|c|c|}
\hline Variables & Definitions & Sources \\
\hline Price shocks & seen section (3) & $\begin{array}{l}\text { Authors, using IMF WEO }(2017)^{20} \text { and } \\
\text { FAO STATISTIQUES }(2016)\end{array}$ \\
\hline Civil conflict & $\begin{array}{l}\text { Dummy variable that takes a value of } 1 \text { if a country experiences } \\
\text { an intrastate conflict with more than } 25 \text { battle deaths and } 0 \\
\text { otherwise }\end{array}$ & $\begin{array}{l}\text { PRIO Uppsala Conflict Data Program } \\
\text { (UCDP) (2017) }\end{array}$ \\
\hline Conflict Intensity & $\begin{array}{l}\text { Conflict Intensity: this is the yearly the number of conflicts that } \\
\text { lead to at least } 25 \text { battle deaths }\end{array}$ & $\begin{array}{l}\text { PRIO Uppsala Conflict Data Program } \\
\text { (UCDP) (2017) }\end{array}$ \\
\hline Government Crisis & $\begin{array}{l}\text { Is the dummy variable, that takes a value of } 1 \text { if there is any } \\
\text { manifestation of government crisis and } 0 \text { if not }\end{array}$ & $\begin{array}{l}\text { Cross-National Time-Series Data Archive } \\
\text { (CNTS). }\end{array}$ \\
\hline Expropriation & $\begin{array}{l}\text { Is the dummy variable, that takes a value of } 1 \text { if there is any } \\
\text { manifestation with a risk of expropriation and } 0 \text { otherwise }\end{array}$ & $\begin{array}{l}\text { Cross-National Time-Series Data Archive } \\
\text { (CNTS). }\end{array}$ \\
\hline Gov Expenditure & Government consumption expenditure annual growth & Authors, using WDI (2015) \\
\hline Fiscal Stimuli & $\begin{array}{l}\text { Dummy variable that takes value } 1 \text { if there are fiscal stimuli and } \\
0 \text { otherwise. }\end{array}$ & Authors, using WDI (2015) \\
\hline Remittances & Net personal remittances received as $\%$ of GDP & WDI (2015) \\
\hline GDPgrowth & The annual rate of GDP growth & Computed using WEO (2016) data \\
\hline $\begin{array}{l}\text { IMF-World Bank } \\
\text { Program }\end{array}$ & $\begin{array}{l}\text { IMF-World bank Poverty reduction program, this is a dummy } \\
\text { variable that take a value of } 1 \text { if the country is on program and } 0 \\
\text { otherwise }\end{array}$ & $\begin{array}{l}\text { (Dreher, Sturm, and Vreeland 2009) and } \\
\text { the latest updated version. }\end{array}$ \\
\hline Private Credit & $\begin{array}{l}\text { Bank and financial credit held by the private sector (as a share of } \\
\text { GDP). }\end{array}$ & WDI (2015) \\
\hline Financial Crisis & $\begin{array}{l}\text { Number of Systemic Banking Crisis, Currency Crisis. } \\
\text { Sovereign Debt Crisis and Sovereign Debt } \\
\text { Restructuring }\end{array}$ & Laeven \& Valcencia(2018) \\
\hline
\end{tabular}

Source: Authors computations

\footnotetext{
${ }^{20}$ World Economic Outlook (2015) World Bank Indicator
} 
Table 10. Summary statistics

\begin{tabular}{lccccc|}
\hline Variable & Observations & Mean & Standard. Deviation. & Minimum & Maximum \\
\hline Civil Conflict & 677 & 0,69 & 0,46 & 0,00 & 1,00 \\
Conflict Intensity & 741 & 1,80 & 1,33 & 1,00 & 9,00 \\
Government Crisis & 4432 & 0,10 & 0,29 & 0,00 & 1,00 \\
Expropriations & 4432 & 0,03 & 0,16 & 0,00 & 1,00 \\
Shock & 3779 & 0,07 & 0,16 & $-0,33$ & 0,84 \\
Positive Shock & - & 2,30 & 1,39 & 0,00 & 4,00 \\
Gov expenditure & 2429 & 5,14 & 28,36 & $-82,33$ & 1004,60 \\
Fiscal Stimuli & 4431 & 0,37 & 0,48 & 0,00 & 1,00 \\
Remittances & 3145 & 4,67 & 8,56 & 0,00 & 106,48 \\
GDPgrowth & 3929 & 0,02 & 0,07 & $-0,61$ & 1,40 \\
IMF-World Bank Program & 4399 & 0,04 & 0,21 & 0,00 \\
Private Credit & 2702 & 0.08 & 0.30 & 0 \\
\hline
\end{tabular}


Table 11. List of countries

\begin{tabular}{|c|c|c|c|c|c|}
\hline \multicolumn{4}{|c|}{ Considered (with at least one observation) on the regressions of government crises } & \multicolumn{2}{|c|}{$\begin{array}{l}\text { Considered (with at least one observation) on the } \\
\text { regressions of civil conflict }\end{array}$} \\
\hline Algeria & Ecuador & Madagascar & Rwanda & Algeria & Mexico \\
\hline Bangladesh & Egypt & Malawi & Senegal & Bangladesh & Morocco \\
\hline Belize & El Salvador & Malaysia & Sierra Leone & Burkina Faso & Mozambique \\
\hline Benin & Equatorial Guinea & Maldives & South Africa & Burundi & Nepal \\
\hline Bhutan & Fiji & Mali & Sri Lanka & Cambodia & Niger \\
\hline Bolivia & Gabon & Mauritania & Sudan & Cameroon & Nigeria \\
\hline Botswana & Gambia & Mauritius & Suriname & Chad & Pakistan \\
\hline Brazil & Ghana & Mexico & Swaziland & China & Papua New Guinea \\
\hline Burkina Faso & Guatemala & Mongolia & Syria & Colombia & Peru \\
\hline Burundi & Guinea & Morocco & Tanzania & Comoros & Philippines \\
\hline Cambodia & Guinea-Bissau & Mozambique & Thailand & Congo & Rwanda \\
\hline Cameroon & Honduras & Namibia & Togo & Cote d'Ivoire & Senegal \\
\hline Cape Verde & India & Nepal & Tunisia & Djibouti & Sierra Leone \\
\hline Chad & Indonesia & Nicaragua & Turkey & Ecuador & South Africa \\
\hline Colombia & Iran & Niger & Uganda & Egypt & Sri Lanka \\
\hline Comoros & Jamaica & Nigeria & Vanuatu & El Salvador & Sudan \\
\hline Congo & Jordan & Pakistan & Venezuela & Guatemala & Syria \\
\hline Costa Rica & Kenya & $\begin{array}{l}\text { Panama } \\
\text { Papua New }\end{array}$ & Vietnam & Guinea & Thailand \\
\hline Cote d'Ivoire & Laos & Guinea & & Indonesia & \\
\hline Republic of the Congo & Lebanon & Paraguay & & & \\
\hline Djibouti & Lesotho & Peru & & & \\
\hline Dominican Republic & Liberia & Philippines & & & \\
\hline
\end{tabular}

